Waldo Romo

Profesor de la Facultad de Teología

Pontificia Universidad Católica de Chile

\title{
Credibilidad de la enseñanza de la Iglesia sobre la sexualidad
}

El tema es complejo y es arduo. También es ambicioso. No se trata de saber lo que la Iglesia enseña sobre el comportamiento sexual. Eso está claro y bastaría para hacerlo patente recoger la clara síntesis que se contiene en el Catecismo de la Iglesia Católica al presentar la doctrina acerca del sexto mandamiento (1). El asunto es dar razón de la credibilidad de esa enseñanza doctrinal. Si siempre es necesario dar razón de nuestra fe y de nuestro modo de comportamiento, ello no significa asumir un camino fideísta sino que, a partir de nuestra elección creyente y anclada en ella, dar cuenta de la legitimidad de la opción cristiana y construir una respuesta que tenga en cuenta la cultura (2), es decir, aquellas formas compartidas de lenguaje que permiten tener como verdaderos tales o cuales conceptos y enseñanzas. El centro del enfoque en el trabajo no es la doctrina sobre la sexualidad sino como se ha elaborado o elabora esa enseñanza, como se dice verdad (veridicción) en nuestra cultura, de modo que esa doctrina sea adecuadamente acogida, hacerla creíble, y permita afirmar que ella no va contra la racionabilidad humana y que vivir tales o cuales comportamientos sexuales son buenos, hermosos y humanizadores.

Decíamos que el tema es complejo y es arduo hasta el punto que es posible compartir la siguiente afirmación: "La situación es tanto más intranquilizante, cuanto que en la actualidad no existe ningún terreno en el que sea tan grande la discrepancia entre la enseñanza que propone el Magisterio de la Iglesia y las convicciones según las que de hecho viven muchos creyentes, como en las cuestiones que se refieren a la sexualidad y el matrimonio" (3).

(1) Cf. Catecismo de la Iglesia Católica nn.2331-2400

(2) Hay diversas concepciones de cultura. Una de las más frecuentes identifica cultura con persona "culta". Aquí asumimos el concepto de cultura propuesto por la ponencia-marco de este Seminario que la entiende como un "sistema simbólico históricamente construido. No se trata de conocimientos o refinamientos que tendrían unas elites intelectuales o artísticas, sino de las formas o sistemas simbólicos que operan de manera subterránea en el discurrir cotidiano de la gente, dando lugar a lo que el Concilio llama "estilos de vida común", Verdugo, F., Consideraciones preliminares sobre la credibilidad”, p. 190.

(3) Kasper, W., Teología del Matrimonio, Santander, 1980, p.10. 
Kasper no se refiere a los que viven fuera de la Iglesia donde sería más comprensible esta discrepancia. Se refiere a los que se consideran miembros de la comunidad cristiana, dentro de la cual se podría pensar que hay mayor fidelidad a los valores propuestos por la Iglesia en el campo de la sexualidad. La "contestación" alcanza también a parte importante de esos creyentes. "...Muchos miembros de la Iglesia tienen dificultad en identificarse con la enseñanza, la moral, las cualidades del matrimonio, tal como las entiende y explica la misma Iglesia... se da un rechazo positivo de no pocos miembros de la misma institución, configuración canónicoeclesiástica y forma de celebrar el matrimonio, tal como la propone la Iglesia... en muchos aspectos se percibe un desfase entre la teología y el derecho, entre la teoría y la realidad, entre los datos de las ciencias humanas y las exigencias de la moral eclesial, entre lo que la celebración expresa y lo que la situación vital supone" (4).

Podrán considerarse muchas explicaciones para esta "contestación". La más básica y fundamental será la ratione peccati. La soberbia humana que no acepta la invitación de Dios al arrepentimiento. Es claro que ella está presente y nunca puede dejar de tenerse en cuenta hasta el punto que la vida humana ante Dios conlleva la exigencia de una conversión permanente. Otra explicación se encontrará en la natural distancia entre los ideales que proclama el Evangelio y nuestra pobre realidad herida por el pecado. También es una explicación válida. Un tercer motivo estará en el impacto que produce el proceso de secularización contemporáneo al interior de las mismas comunidades cristianas (5). Llama la atención, sin embargo, por qué este cuestionamiento a la enseñanza de la Iglesia tiene su punto de máxima distancia, como expresa Kasper, en el campo de la sexualidad. Si la razón queremos encontrarla en "la debilidad de la carne" exclusivamente, podríamos estar privilegiando en demasía una moral centrada primordialmente en las faltas de índole sexual, en contraste con la manera como Jesús se refiere a la soberbia, el egoísmo, la doblez y la dureza del corazón del fariseo y del rico Epulón.

La explicación puede encontrarse, también, en la manera como se estructura el discurso moral que presenta carencia de mediaciones culturales cuando se refiere al campo de la sexualidad, las cuales, sin embargo, son admitidas, con frecuencia, en el discurso sobre la moral social.

En cierta manera la insuficiencia en la "veridicción" de la enseñanza sobre la sexualidad ha sido recogida por la reflexión moral contemporánea al distinguir el ámbito de la moral formulada y el de la moral vivida. Es verdad que esta distinción cabe en todas las dimensiones del comportamiento moral pero tiene una especial relevancia en el campo que estamos tratando. Respecto a la moral formulada, la reflexión teológico-moral no puede realizarse dentro de los límites autojustificantes de un positivismo bíblico o dogmático. El positivismo teológico ha entrado en crisis. La reflexión teológico-moral debe ir por los cauces de una metodología que incorpore el horizonte de la interdisciplinariedad. Es necesario agregar "el mundo" como un nuevo "lugar teológico", lo que implica realizar el discurso teológico-moral a través de las mediaciones de otros saberes interdisciplinares vinculados a la teología. "Si la meto-

(4) Borobio, D., Celebración en la Iglesia, T.II, Salamanca, 1985, p. 505.

(5) Cf. Encíclica Evangelium Vitae n. 21,1. 
dología del saber teológico-moral no se autojustifica desde dentro de su autonomía, ello depende de que la normatividad ética cristiana no puede ser tematizada, es decir, sometida a un discurso crítico, si este no se sirve de mediaciones ético-antropológicas. Esta afirmación descansa sobre otra más amplia: la 'gracia' presupone la 'naturaleza'. Afirmación que en el terreno del saber teológico-moral ha tenido una versión particular: para no caer en una especie de 'fideísmo moral' se requiere aceptar la validez de la normatividad humana como mediación que expresa y encarna la normatividad cristiana. En los últimos años se ha insistido dentro de la moral católica en la importancia y necesidad de la normatividad humana y de racionalización como preámbulo, horizonte y contenido de la ética cristiana" (6).

En relación con la moral vivida queda claro que la opción creyente no se reduce a un empeño ético. Sin embargo, no tiene sentido una fe que no se traduzca en una serie de decisiones compromitentes. Un cristiano está llamado a asumir una conducta de modo tal que su vida no sea ni un "moralismo" vaciado de lo religioso ni un "supranaturalismo" vaciado de lo moral. El equilibrio, que permite evitar ambos extremos, se encuentra en comprender la peculiar función de la actitud y el valor morales. "La actitud moral para un cristiano brota de la vivencia religiosa y, al mismo tiempo, sirve de mediación entre la fe y el compromiso. El valor moral tiene una función entre los valores religiosos y todos los restantes valores. Se puede decir que el valor moral está presente de una manera especial en todos los demás valores sin privarlos de su autonomía y peculiaridad" (7).

El sentido moral en un cristiano tiene una vinculación necesaria con su opción de fe. Si hay un predominio de la moralidad sobre la vivencia religiosa, se caería en una concepción "moralizante" del cristianismo. La primacía de la fe descarta una comprensión de la moral como puro "moralismo". Pero, a su vez, la dimensión religiosa no se puede convertir en un puro "supranaturalismo" que no tiene incidencia alguna con el compromiso transformativo de la realidad. El sentido moral para un cristiano brota de la vivencia religiosa y, al mismo tiempo, sirve de mediación entre la religión y el compromiso al interior del mundo. La posibilidad que tiene la fe de hacerse coherente está en la asunción de un êthos cristiano, despertando a aquella de su "sueño dogmático" o del peligro de enclaustrarse en un "misticismo autogratificante". La vida de un cristiano, llevada a cabo bajo el signo de la forma de todas las virtudes, la caridad, no puede encerrarse sobre ella misma. Necesita convertirse en la fuerza transformadora de la realidad humana. "La ética, tanto en el plano de la reflexión como en la acción, sirve de verificación del carácter 'operativo' del kerigma cristiano y del discurso teológico que lo tematiza" (8).

Es verdad, como lo hemos expresado, que la fe necesita la mediación operativa de la ética. Pero el compromiso moral requiere, a su vez, para expresarse y vivirse, de otras mediaciones. La principal de ella es la transformación de la realidad. La ética del cristiano tiene sentido y coherencia cuando se convierte en praxis (9).

(6) Vidal, M., Moral Fundamental, Madrid, 1990, p.191.

(7) O.c. 188

(8) Simón, R., Fundar la moral, Madrid, 1976, p.12.

(9) La más breve y profunda definición de moral cristiana es entenderla como "la praxis de la fe". 
"Esta afirmación inicia un tema decisivo de la ética en la medida en que es mediación de una fe y, por otra parte, en la medida en que se sirve de mediaciones transformativas de la realidad humana. En esa doble función mediadora reside el misterio y la fuerza del compromiso ético cristiano" (10).

Llevemos estas consideraciones al tema en estudio. Es posible que el modo de proponer la enseñanza moral en el ámbito de la sexualidad o la manera en que aquella ha sido entendida sea el de un exclusivo moralismo falto de aliento evangélico o basado solo en un positivismo bíblico o dogmático. También puede percibirse como una enseñanza que arranca de una vivencia cristiana propuesta de modo ahistórico y acomprometido -lo que llamamos "supranaturalismo"- que no tiene en cuenta la realidad ni asume las mediaciones culturales en que ella debe expresarse. Se trataría, entonces, de ofrecer una enseñanza que, para ser creíble, debiera "estar en el mundo pero de modo diferente" (11), es decir, no ser eco repetitivo de lo que dice la cultura actual simplemente porque hay que estar con la contemporaneidad. Eso sería la peor de las razones y el Evangelio dejaría de ser interpelante. Se trata de entender las claves de comprensión de una cultura para entrar desde ellas con el fermento crítico evangélico que, en ocasiones, plantea criterios "contraculturales".

Decíamos, también, que el tema es ambicioso. En efecto, más son las preguntas que las respuestas que se presentan ante los desafíos contemporáneos a la credibilidad de la enseñanza de la Iglesia sobre la sexualidad. El situar bien las interrogantes y acotar con una cierta precisión las áreas problemáticas será ya un modesto resultado de este trabajo. Señalar, "con temor y temblor", algunos caminos de respuesta a esos desafíos podrá ser un segundo fruto. Sin embargo, a observadores críticos de esas pistas les podrán parecer insuficientes; otros, en cambio, exageradas. Por el estrecho desfiladero que implica ser fiel a la enseñanza de la Iglesia y ser fiel a la cultura y a las voces de nuestro tiempo, procuraremos avanzar. El riesgo de errar o caer en ambigüedades estará siempre presente, especialmente en la esfera de la moral sexual, más que en otros campos de la moral cristiana (12). Intentar puentes de diálogo con la cultura contemporánea, manteniendo la fidelidad a la enseñanza doctrinal de la Iglesia, no es un trabajo en modo alguno fácil. Hacer una moral en situación que no llegue a ser una moral de situación es otro serio problema (13). Lo

(10) Vidal, M., o.c. 188-189.

(11) En el plano de los comportamientos, hay que integrar, también, estos dos momentos: "estar" pero "de modo diferente". Hay cristianos, tan evadidos de las situaciones, que se vuelan en el universo de los principios absolutos y nunca toman en cuenta la realidad. Otros, en cambio, viven tan "aterrizados" en las situaciones que se mimetizan con ellas y no las interpelan ni las cuestionan desde las exigencias evangélicas.

(12) Es lo que ha ocurrido con algunos maestros contemporáneos de la teología moral. Llama la atención que en la Notificación del Vaticano sobre parte de la obra del moralista español P. Marciano Vidal, de las siete observaciones críticas en las cuestiones particulares, cuatro se refieren a temas específicos de moral sexual: métodos interceptivos para regular la natalidad, homosexualidad, masturbación, procreación responsable. Los otros temas observados se refieren a moral de la vida que de alguna manera están vinculados al ejercicio de la sexualidad: esterilización, fecundación in vitro homóloga y heteróloga y el tema de las leyes abortivas. Cfr. Congregación para la doctrina de la fe, Notificación acerca de algunos escritos del Rev. P. Marciano Vidal, C.Ss.R. del 22 de febrero de 2001.

(13) "Una década antes del Concilio, Pío XII condenó lo que se llamó en ese momento 'la ética de situación’. El contenido de esta expresión implicaba en la práctica la negación de las normas 
expresado nos conduce a un tema muchos más amplio y complejo que supera el objetivo de este trabajo: el servicio de los teólogos moralistas al interior de la Iglesia y su vinculación con el Magisterio (14).

Para los efectos de avanzar con un suficiente rigor, estructuraremos el trabajo siguiendo tres pasos: A) Concepto y contenido de la sexualidad humana. B) Sinopsis histórica de la enseñanza de la Iglesia sobre la sexualidad. C) Desafíos contemporáneos sobre la credibilidad de la enseñanza de la Iglesia con respecto a la sexualidad.

morales que tuviesen relación vinculante con el comportamiento de la persona. El único criterio válido para la conducta moral era la situación, sin poder señalarse principios válidos que orientaran el obrar humano. Era la exageración absoluta del 'aquí' y 'ahora' que pasaba a ser el factor determinante y no condicionante de la moral. Para evitar este situacionismo, eliminador de la normatividad ética, se dio demasiada importancia a lo que se obraba, es decir, a una moral del objeto, dejando en menor importancia a quien es el que obraba, es decir, una persona que siempre se encuentra en una coyuntura. Valorar la situación no es negar la validez de los principios y normas morales. Solo que se trata de aterrizar dichas exigencias a la persona que se encuentra en una situación determinada. La moral de la persona en situación da gran importancia a la realidad, partiendo de ella para hacer aquel discernimiento. Es el 'ver' del método pastoral que no se queda ahí. Hacerlo sería permanecer en la descripción de la realidad. La situación es iluminada con el 'juzgar' del Evangelio para concluir con el 'actuar' que es el esfuerzo por acercar normatividad a coyuntura, principios a situación”. Romo, W., Texto de Moral Fundamental, Instituto Profesional Hogar Catequístico, Santiago, 2002, pp.76-77.

(14) Cf. Encíclica Veritatis Splendor 109-113. Destacamos algunos aspectos relevantes del documento en esta materia: "Ciertamente, la teología moral y su enseñanza se encuentran hoy ante una dificultad particular. Puesto que la doctrina moral de la Iglesia implica necesariamente una $d i$ mensión normativa, la teología moral no puede reducirse a un saber elaborado solo en el contexto de las así llamadas ciencias humanas. Mientras estas se ocupan del fenómeno de la moralidad como hecho histórico y social, la teología moral, aun sirviéndose necesariamente también de los resultados de las ciencias del hombre y de la naturaleza, no está en absoluto subordinada a los resultados de las observaciones empírico-formales o de la comprensión fenomenológica. En realidad, la pertinencia de las ciencias humanas en teología moral siempre debe ser valorada con relación a la pregunta primigenia: ¿Qué es el bien o el mal? ¿Qué hacer para obtener la vida eterna?" (n.111,2). "El teólogo moralista debe aplicar, por consiguiente, el discernimiento necesario en el contexto de la cultura prevalentemente científica y técnica actual, expuesta al peligro del pragmatismo y del positivismo. Desde el punto de vista teológico, los principios morales no son dependientes del momento histórico en el cual vienen a la luz. El hecho de que algunos creyentes actúen sin observar las enseñanzas del Magisterio o, erróneamente, consideren su conducta como moralmente justa cuando es contraria a la ley de Dios declarada por sus Pastores, no puede constituir un argumento válido para rechazar la verdad de las normas morales enseñadas por la Iglesia. La afirmación de los principios morales no es competencia de los métodos empírico-formales. La teología moral, fiel al sentido sobrenatural de la fe, sin rechazar la validez de tales métodos -pero sin limitar tampoco a ellos su perspectiva-, mira sobre todo a la dimensión espiritual del corazón humano y su vocación al amor divino" (n.112,1). "Si la convergencia y los conflictos de opinión pueden constituir expresiones normales de la vida pública en el contexto de una democracia representativa, la doctrina moral no puede depender ciertamente del simple respeto de un procedimiento; en efecto, esta no viene determinada en modo alguno por las reglas y formas de una deliberación de tipo democrático. El disenso, a base de contestaciones calculadas y de polémicas a través de los medios de comunicación social, es contrario a la comunión eclesial y a la recta comprensión de la constitución jerárquica del Pueblo de Dios..." $(113,2)$. El oficio del teólogo, como servicio a la Iglesia, implica estar en comunión con el Magisterio pero no constituirse en un simple comentador o glosador del mismo. Su tarea de pensar la fe es irrenunciable y la propia Encíclica lo reconoce. Ese diálogo con las voces de nuestro tiempo es un aporte imprescindible, ofreciendo, así, una preciosa ayuda a la formulación de las mismas enseñanzas doctrinales del Magisterio para que ellas sean comprensibles y creíbles en una época histórica determinada. A la luz de lo expuesto, en estricta lógica el mismo disenso no está excluido. Se rechaza aquel que se realiza "a base de contestaciones calculadas y de polémicas a través de los medios de comunicación social”. Un disenso respetuoso, fiel a la comunión con los Pastores, sin 


\section{CONCEPTO Y CONTENIDO DE LA SEXUALIDAD HUMANA}

Hablando con propiedad, la propuesta sobre el concepto y contenido de la sexualidad humana que ofrecemos responde a la asunción contemporánea de una reflexión sobre la riqueza de la sexualidad en nuestra especie que supera el puro dato biológico. Lo corroboran tanto documentos del Magisterio (15) como autores que han abordado el tema desde el campo de la psicología, psiquiatría y medicina (16). Así expresado, en estricta lógica esta parte del trabajo debería presentarse a continuación de la sinopsis histórica porque daría cuenta del punto al cual hemos llegado y en el cual estamos. También nos permitiría apreciar las concepciones que se han ido superando y los

las características del disenso que se objeta, ¿no podría constituir un verdadero servicio a la Iglesia? La enseñanza tradicional de la Iglesia expresa la competencia del Magisterio en materia de "fe y costumbres" pero también deja claro los distintos niveles de sus pronunciamientos. Es claro que muchas de las enseñanzas de la Iglesia en materia de teología moral forman parte del magisterio ordinario y la manera de asumirlas y obedecerlas sigue los criterios expresados en Lumen Gentium, 25. Cabe preguntarse, sin embargo, qué enseñanza en la esfera de la moral se ha pronunciado con carácter solemne o extraordinario de modo que estemos ante una doctrina definitiva e infalible. No hay duda que ello se ha dado con claridad en la esfera del dogma. La pregunta toca al ámbito de "las costumbres" (la moral) y es un punto técnico en la enseñanza de la teología moral sometido a debate. Diversos teólogos moralistas, aunque no es un pensamiento unánime, estiman que los planteamientos de Juan Pablo II en Evangelium Vitae sobre la eliminación directa y voluntaria de un ser humano inocente (E.V.57,4), sobre el aborto directo, es decir, querido como fin o como medio (E.V.62,3) y sobre la eutanasia directa (E.V.65,4) se inscribirían en esa línea de pronunciamientos magisteriales solemnes y extraordinarios. Al parecer, no podría decirse lo mismo sobre otras materias de índole moral, contenidas en algunas Encíclicas, como es el caso de la regulación de la natalidad respecto a los métodos empleados para hacerla posible. Refiriéndose a Humanae Vitae algunos episcopados señalan: "Cuando no nos encontramos ante una declaración infalible y por tanto irreformable -lo que no suele ser el caso de una encíclica y que Humanae Vitae, por de pronto, no reivindica para sí- no estamos obligados a dar un adhesión incondicional absoluta, como la que exige una definición dogmática..." (Obispos belgas en Declaración sobre la referida Encíclica); "Por el hecho de que la encíclica no contiene ninguna sentencia infalible en materia de fe, pudiera darse el caso de que alguno creyera no poder aceptar el juicio del magisterio de la Iglesia. Sobre este punto es necesario responder esto: el que es competente en este terreno y ha llegado a esta convicción divergente después de un estudio serio y no de una manera prematura y afectiva, puede seguirla en primera instancia. No se equivoca si está presto a proseguir la investigación y a permanecer, por otra parte, respetuoso y fiel con respecto de la Iglesia. Queda, sin embargo, claro que en tal caso, no tienen derecho a propalar sus opiniones, a sembrar la confusión entre sus hermanos en la fe..." (Obispos austriacos sobre la misma Encíclica). Las declaraciones íntegras de estos y otros episcopados pueden encontrarse en "La Documentation catholique" a partir del n.1523 del $1^{\circ}$ de septiembre de 1968 adelante. Teniendo en cuenta lo expresado, es casi innecesario decir, sin embargo, que el comportamiento de un cristiano no puede moverse en la aceptación de una "moral en el límite", es decir, mientras no sea infalible una enseñanza, se tiene derecho a discrepar. Dicha actitud sería contraria a los criterios planteados en Lumen Gentium que nos hablan de un "obsequio religioso de la voluntad y del entendimiento" ante el magisterio auténtico aunque no se esté hablando ex cathedra (n.25). Es la connatural actitud de un cristiano que quiere vivir en comunión con los Pastores. Con todo, en el servicio del teólogo de dar razón de la fe, la no infalibilidad de un documento supone que una enseñanza no está cerrada y es válido llevar adelante estudios e investigaciones para presentar respetuosamente las conclusiones en fidelidad a la Iglesia. El problema de la veridicción ("decir verdad") de una enseñanza exige esta capacidad de reflexión en comunión con los pastores y como un aporte específico del papel del teólogo moralista al interior de la comunidad eclesial.

(15) Cf. Sagrada Congregación para la Educación Católica, Orientaciones educativas sobre el Amor humano. Pautas de educación sexual, Roma, 1983; Constitución Pastoral Gaudium et Spes,51,3.

(16) Cf. Schwartz, O., Psychologie Sexuelle, París, 1952; Oraison, M. Le mystère humain de la sexualité, París, 1966; López Ibor, J.J., El libro de la vida sexual, Barcelona, 1977. 
aspectos en los cuales es necesario seguir trabajando Sin embargo, hemos optado por mantener este ordenamiento para ofrecer un marco teórico adecuado a la luz del cual puedan evaluarse las insuficiencias, los descubrimientos y los avances en la elaboración doctrinal de la Iglesia en su enseñanza sobre la sexualidad. También permite valorar positivamente, desde ya, el aporte del Concilio Vaticano II, en la Gaudium et Spes, que propone una enseñanza sobre la sexualidad y el amor en fidelidad al aliento bíblico y abierto a las voces de nuestro tiempo.

El contenido de la sexualidad en nuestra especie supera, con mucho, la pura dimensión corporal. Explicarla desde esta exclusiva mirada es asumir un enfoque reduccionista de una realidad compleja y se traduce, en definitiva, en no entender la riqueza de contenido que ella involucra. Es necesario evitar, también, el error contrario: "espiritualizar" tanto la reflexión que se omita su raigambre biológica. En ambos extremos se termina por deformar el sentido de la sexualidad humana. Es necesario recordar, de inmediato, que el punto de arranque de la significación de la sexualidad humana se encuentra en su base física. La corporalidad sexuada de un macho y una hembra es el basamento sobre el cual se despliega la condición de ser varón o ser mujer, de lo masculino o de lo femenino. Un ser puramente espiritual no posee sexualidad porque no tiene genitalidad. Esta continuidad con la base del animal irracional y la superación de ese mundo, trascendiéndolo, se encuentra en el núcleo de nuestra reflexión. "El hombre es un ser vivo como otros, y sin embargo, es radicalmente diferente. A la luz de la ciencia moderna se puede describir su situación como la de un ser vivo que emerge del proceso evolutivo y que alcanza una modalidad de ser absolutamente diferente del universo de donde viene. La expresión somática de este cambio se encuentra sobre todo en el considerable desarrollo del cerebro, es decir, en una profusión tal de conexiones intracerebrales que lo 'imprevisible' se introduce en el sistema de sus reacciones con el mundo" (17).

Si observamos el comportamiento humano en el ámbito de la sexualidad descubrimos diversos aspectos, siendo uno de ellos la fuerza, la energía y la motivación que representa en la especie. Es verdad que no constituye la única fuerza que motiva al ser humano, aunque existan corrientes de pensamiento que así quieran afirmarlo. Sin embargo, si tomamos conciencia que siempre nuestra conducta es sexuada -actuamos permanentemente en 'sintonía masculina o femenina' según seamos varón o mujer- afirmamos que la sexualidad, en ese sentido integral, se nos impone por sobre nuestras opciones y nos define nuestro modo de ser y existir.

Ante este hecho, surge una pregunta: ¿por qué tiene tal fuerza en la especie humana esta realidad? Una respuesta inicial será: porque responde al deseo de reproducción. Es una contestación verdadera pero insuficiente. Es cierto que tras esa fuerza está el deseo de transmitir la vida, anclada en la genética de todo ser viviente. Es lo que llamamos el instinto de reproducción. Por ello estamos en condiciones de hablar de una "cierta base común" en el ámbito de la sexualidad, que se expresa en la existencia de seres anatómicamente diferentes (varón y mujer en la especie humana; macho y hembra en el mundo animal); en la emisión de productos sexuales masculinos (espermatozoides) y femeninos (óvulos); en preponderancias

(17) Oraison, M., o.c. 18. 
hormonales específicas según los sexos; en una cierta "atracción” a partir de la diferenciación anatómica, glandular y hormonal; en la posibilidad de un encuentro heterosexual gobernado por un conjunto de reflejos innatos.

No obstante, esta respuesta inicial es insuficiente por dos motivos: no solo el ser humano se reproduce ni tampoco todo miembro de la especie humana transmite la vida desde el punto de vista biológico y, sin embargo, todos los seres humanos poseen sexualidad. Estamos buscando una respuesta exclusiva para nuestra especie y que abarque a todos sus miembros. Por ello la pregunta inicial se desplaza a otras interrogantes: ¿basta lo que hemos señalado en el párrafo anterior para explicar la fuerza de la sexualidad en nosotros? ¿Hay una real identidad entre lo que ocurre en algunas especies animales y en el ser humano que permita una explicación común? Analicemos más de cerca esa "cierta base común" desde una perspectiva amplia y no desde una óptica de materialismo biológico dentro de la cual el ser humano es concebido como un animal un poco más evolucionado y complejo que el resto de los animales. Carentes de inteligencia -al menos hasta el nivel al cual puede llegar la especie humana- y de capacidad de elección entre alternativas para superar sus dificultades, los animales suplen esta circunstancia con un instinto perfecto que se va adecuando a las necesidades de su existencia. Esto se manifiesta en que desde pequeño -y habría innumerables ejemplos para corroborar lo señalado- el animal utiliza su instinto sin mayor aprendizaje para enfrentar las dificultades que le plantea el medio. El ser humano, en cambio, no tiene tal perfección del instinto, pero ello no es una carencia ni un defecto, ya que supera largamente, con elementos específicos de orden superior, esa ausencia. Su inteligencia y su libertad le permite ser no programado, reconstruir en forma nueva, ser irrepetible e imprevisible, según la expresión de Oraison.

Esta capacidad inventiva es, sin embargo, potencial. La superación de las dificultades del medio, la posibilidad de establecer lúcidamente sus elecciones suponen en nuestra especie un desarrollo gradual, personal y consciente de la inteligencia y libertad. Este desarrollo, además de la maduración biológica, se lo proporcionará especialmente la educación hasta el punto que cada uno de nosotros estará toda su vida sujeto a situaciones de aprendizaje.

Apliquemos estas consideraciones al ámbito de la sexualidad. En el ser humano las cosas suceden de modo diferente al del mundo animal. La sexualidad ya no es exclusivamente instintiva y hormonal. Los movimientos reflejos no son algo ineludibles y pueden ser "gatillados" bajo la dependencia de la corteza cerebral. Esto es tan cierto que cabe señalar que la persona humana no tiene conocimiento del instinto sexual propiamente dicho: experimenta el deseo de unirse, pero carece de conocimiento innato para qué existe y de sus repercusiones. Mediante la experiencia y la educación irá descubriendo la orientación y el sentido de las pulsiones sexuales. Para que el cerebro humano esté en condiciones de dirigir la actividad sexual necesitará de un periodo largo de crecimiento, desarrollo y equilibrio.

Lo expresado hasta aquí nos permite decir que de manera muy impropia hay tal 'comunidad' de sentidos entre el ser humano y el animal en el mundo de la sexualidad. Más bien las diferencias son tan amplias que podemos afirmar que en la escala de seres vivos, mientras más abundante es la reproducción menor es la comunica- 
ción y encuentro entre los reproductores (18). En efecto, entre los protozoos la muy abundante reproducción no se efectúa por encuentro genital sino por segmentación, de modo que la reproducción es asexuada; en ciertos peces, si bien hay una enorme reproducción, ella ocurre sin contacto genital directo desde el momento que el macho, sin unión con la hembra, fecunda los huevos que esta ha desovado por miles de miles. Si ascendemos en la escala de la vida encontramos que la función sexual es totalmente automática en los invertebrados; ya en los vertebrados superiores hay un evidente progreso: se da el apareamiento, un encuentro individual, una cierta atracción, una vistosidad del macho para atraer a la hembra, un galanteo precoital e incluso, en ocasiones, una permanencia monógama para el cuidado y protección de las crías. En todo caso, esta clara evolución se sitúa en el ámbito de los reflejos automáticos y en vistas de la reproducción. Señalamos, entonces, que en el mundo animal no hay más sexualidad que la necesaria para la reproducción.

En la especie humana se llega a la cumbre de la escala de seres vivos en este mundo. En nosotros, en el campo sexual, se mantiene una gran riqueza de mecanismos reflejos y de complejas corrientes nerviosas. Sin embargo, esa riqueza y complejidad están gobernadas por nuestros centros superiores. Lo propiamente humanizador será que antes de llegar a una intimidad genital se establezca entre varón y mujer un largo camino que comienza con el contacto social juvenil masculino y femenino, sigue -habitualmente- con un proceso de exclusivización de pareja que toma diversos nombres según las culturas ("pololos", enamorados, novios) (19). Este recorrido externo se vincula a un proceso interno de descubrimiento físico, psicológico, afectivo, espiritual. Surge, así, un complejo de relaciones interpersonales de cariño, respeto, admiración, complemento, de modo que el acto sexual, llevado a cabo en un contexto específicamente humano, será no solo camino para transmitir la vida sino también, y al mismo tiempo, podrá llegar a ser un lenguaje de comunicación, un camino de encuentro espiritual mediado por lo corporal. Es claro que desde un punto de vista puramente fenomenológico esta dimensión trascendente de la intimidad genital entre dos personas puede no estar presente. La experiencia del día a día lo corrobora frecuentemente. Sin embargo, ese gesto biológico donde está ausente aquella dimensión se convertirá, entonces, en un simple encuentro coital, epidérmico e "in-significante", es decir, carente de significación, perdiendo, así, la posibilidad de transformarse en un comportamiento humanizador. Se intuye, entonces, que la sexualidad humana tiene un plus más allá de su sola orientación reproductiva dándose la posibilidad en nuestra especie que el comportamiento sexual sea manifestativo del amor humano, es decir, sensible y espiritual al mismo tiempo (20).

Además, con esa carga afectiva, el mismo proceso biológico de re-producir se transforma en un proceso de pro-creación. Estrictamente hablando el animal se reproduce; el ser humano, en cambio, procrea. En la primera situación hay repetición sin novedad, hay otro ser que es un agregado numérico a una bandada de

(18) Ya a fines del siglo XIX el investigador ruso V. Soloviev había hecho esta observación. Cf. Le sens de l'amour, Aubier, 1898.

(19) Cf. Schwartz, O., o.c. y López Ibor, J.J., o.c. 238-247.

(20) Encíclica Humanae Vitae, 9. 
pájaros, un cardumen de peces, un rebaño de ovejas. En la especie humana estamos ante la co-creación de un nuevo ser único e irrepetible en toda la historia de la humanidad. Esta novedad, irreductible a un número más, está dada por la presencia de Dios que al "insuflar su aliento de vida" (Gn 2,7) crea un ser específico y peculiar, llamado a ser inviolable en su dignidad desde el primer momento de su existencia. Esta novedad se ha realizado con la participación de los progenitores que, al abrirse a la vida, han llevado adelante una labor de pro-creación. Para ilustrar de manera pedagógica lo manifestado, recurramos a una comparación: una persona con habilidad pictórica está en condiciones de reproducir un cuadro que ha hecho un gran pintor. Es posible que dicha reproducción sea notable y ejecutada con gran habilidad. Sin embargo, no deja de ser repetición de lo que otro ya hizo. En cambio, si esa misma persona pinta un cuadro que nadie ha realizado, estamos ante una creación artística, ante algo original. Desde la perspectiva creyente, cada ser humano es una originalidad -no una reproducción- desde su inicio. Alguien nuevo está presente en el mundo que antes no estaba. No nos encontramos ante un algo sino ante un alguien, no es un número sino un nuevo ser, que es necesario descubrir y valorar, para que se le respete en su dignidad inviolable, excluyendo una manipulación que lo tratara como un objeto.

El proceso evolutivo que hemos delineado en párrafos anteriores nos exige, en este momento, distinguir con precisión dos términos que están estrechamente vinculados pero que es necesario no identificar: genitalidad y sexualidad.

Desde un punto de vista descriptivo el contenido de la genitalidad comprende el conjunto de características anatómicas, glandulares, fisiológicas y hormonales que distinguen a los seres vivos en función de la reproducción. La sexualidad, también expresada de modo descriptivo, la entendemos como el conjunto de características genitales, afectivas, psicológicas, sociales y ético-espirituales que distinguen y complementan a la mujer y al varón. Ponemos de relieve que se trata de conceptos descriptivos para no entrar, especialmente en el campo de la sexualidad, en su connotación 'mistérica' que no se agota en la conceptualización propuesta. Sin embargo, la descripción planteada tiene su valor. En efecto, en estricta lógica el animal solo posee genitalidad aunque con frecuencia se hable, de modo impropio, de su sexualidad. El ser humano, en cambio, posee ambas, vinculadas en una relación de parte a todo, desde el momento que la genitalidad, en la especie humana, es un aspecto definitorio de su sexualidad, aunque esta tiene otras dimensiones más allá de la sola manifestación biológica. De alguna manera, la genitalidad es extensiva (hablamos de "los seres vivos") y exclusiva (precisamos que es "en función de la reproducción"); la sexualidad, a su vez, también lo es pero desde referentes distintos: es exclusiva porque nos referimos a "mujer y varón" y extensiva ya que destacamos los diversos aspectos que la constituyen.

Tal como lo hemos presentado, la sexualidad en nuestra especie es una realidad compleja y, a la vez, integradora (21). Compleja, en cuanto no se agota en una sola dimensión sino que es polivalente. Integradora, en cuanto ninguno de los aspectos

(21) Todos los tratadistas de teología moral están concordes en este punto, expresándolo de maneras diferentes. Así, Mifsud habla que la sexualidad es una realidad polivalente, destacando diversas "instancias", Mifsud, T., Una reivindicación ética de la sexualidad humana, Santiago, 1999; 
que la constituyen se encuentran desarticulados de los otros. Todos ellos se refieren a una persona que está en una etapa de mayor o menor integración sexual.

El mismo concepto nos lleva a otra consideración: ningún ser humano tiene sexualidad, en el sentido que se trataría de algo que la persona se quita o se pone a voluntad. Cada uno de nosotros es sexuado, en el sentido que la concepción integradora de la sexualidad se identifica con la persona misma: se es varón o se es mujer, incluso en situaciones de homosexualidad. Lo expresado nos lleva a afirmar que la sexualidad en nuestra especie es una manera existencial de darse la esencia humana. Desde el punto de vista metafísico la persona se la ha definido, ya en la antigüedad grecolatina, como una "sustancia individual de naturaleza racional" (Boecio). Pero ese concepto es ontológico, esencial, y como tal "asexuado". Ahora bien, desde una mirada existencial no se da ninguna sustancia individual de naturaleza racional que no sea varón o mujer. No hay un segundo de la existencia humana en que dejemos de vivir 'en sintonía' masculina o femenina. En cambio, decimos que tenemos órganos genitales pero no somos tales órganos. Puede ocurrir, por ejemplo, que un varón haya sufrido en su cuerpo una vasectomía o una mujer haya realizado una ligadura de trompas y no por ello dejará de ser varón o mujer. Es verdad, sin embargo, que si se han amputado las gónadas, se estará afectando profundamente el modo de ser masculino o femenino. Tal situación viene a ser una comprobación clara de la raigambre genital en la cual se asienta la sexualidad humana. La "plataforma de lanzamiento" sobre la cual se despliega la riqueza de la sexualidad en nuestra especie está en el dato biológico. Como ya lo manifestamos, un ser exclusivamente espiritual no posee sexualidad porque no tiene genitalidad. El ser humano, en cambio, es sexuado porque tiene genitalidad (22). Podrá objetarse que otro tanto ocurre en el mundo animal, desde el momento que no hay un segundo de la existencia en que ese animal no sea macho o hembra. Eso es cierto. Pero la conciencia de tal situación no la posee. En cambio, en nuestra especie, la progresiva toma de conciencia de la condición sexuada será fundamental para vivir esa genitalidad 'dada' y no elegida. La sexualidad humana, cuando se manifiesta en comportamiento, es una opción que se puede hacer. La genitalidad es una realidad que está en nosotros; la sexualidad, en cambio, es una realidad que hacemos nuestra (23). Las consecuencias de esta básica distinción entre los conceptos planteados son muchas y superan los objetivos de este trabajo.

En el esfuerzo por "decir verdad" (veridicción) acerca de la sexualidad desde el campo de la teología moral y tomando en cuenta el aporte de otras disciplinas, mencionemos dos de esas consecuencias: en primer lugar, la distinción entre madurez genital y madurez sexual, la cual será fundamental para entender situaciones de crecimiento psicosexual y las consiguientes etapas que se viven en ese proceso. El punto será decisivo a la hora de realizar un discernimiento moral sobre ciertas

Vidal señala la idea refiriéndose a las diversas "dimensiones" de la sexualidad, Vidal, M., Moral del amor y de la sexualidad, Madrid, 1991; López Azpitarte manifiesta los significados y simbología de la sexualidad, López Azpitarte, E., Ética de la sexualidad y del matrimonio, Madrid, 1992.

(22) La concepción de Yahvé Dios, el radicalmente Otro, puramente espíritu, está más allá de la sexualidad masculina o femenina. Jesucristo, Dios encarnado, es varón porque posee genitalidad. "Igual en todo a nosotros, salvo en el pecado".

(23) Hortelano habla de la sexualidad como un instinto 'en mí' y la sexualidad como una vivencia 'mía'. Hortelano, A., Problemas actuales de moral, T.II, Salamanca, 1980, pp. 274-279. 
conductas sexuales. En segundo lugar, la diferencia entre instrucción genital y educación sexual, distinción en la cual el pensamiento de la Iglesia contemporánea ha hecho aportes significativos incorporando la rica elaboración de una sociología y una psicología que tiene en consideración una adecuada antropología filosófica.

\section{SINOPSIS HISTÓRICA DE LA ENSEÑANZA DE LA IGLESIA SOBRE LA SEXUALIDAD}

Este segundo paso del trabajo tiene por objeto presentar la manera como fue elaborándose la doctrina de la Iglesia sobre la sexualidad a lo largo de los siglos. Qué antropología de base empleó; qué "adherencias" culturales asumió; qué errores debió combatir y que permiten entender, en definitiva, énfasis doctrinales; qué biología y conocimientos científicos en el campo médico se manejaban en otros siglos y que la Iglesia tuvo en consideración al hacer sus planteamientos. Esta sinopsis histórica nos permite, entonces, entrar en el esfuerzo histórico de la Iglesia por inculturar el designio de Dios sobre la sexualidad, el amor y el matrimonio contenido en la Sagrada Escritura, la cual, como es natural incorpora -a su vez- sus propias recepciones culturales vetero y neotestamentarias. En este intento de "decir verdad" nos encontraremos con aspectos que fueron pacíficamente aceptados, otros que se expresaron en condenas magisteriales ante posiciones claramente heréticas, unos terceros que fueron evolucionando a la par de nuevos conocimientos y unos últimos, finalmente, que han empezado a ser sometidos a cuestionamientos a partir de planteamientos que provienen de la cultura moderna y postmoderna. "Se hace del todo necesario abocarnos a este análisis, cuando pensamos que gran parte de esa formulación ha dependido de una comprensión antropológica que echa sus raíces en la antigüedad y que, en más de algún punto, no es concordante con la visión que del hombre y su actividad nos aportan las investigaciones empíricas contemporáneas" (24). Es necesario tener presente, además, que parte del debate teológico pre y post Humanae Vitae ha sido de tipo histórico, hasta el punto que temas como "la naturaleza del acto" y "el acto de la naturaleza" es necesario situarlos en el contexto de su evolución histórica para una adecuada crítica y comprensión.

El tema propuesto es muy amplio y hacer una investigación exhaustiva es competencia de una tesis y no de una ponencia como la presente. También los estudios existentes en el campo teológico se refieren mayoritariamente a la teología del matrimonio (25) más que a la misma sexualidad. Sin embargo, al reflexionar sobre el matrimonio y su sacramentalidad desde el punto de vista histórico, hay, como es lógico, una necesaria referencia al modo de entender la sexualidad en las diversas épocas. Con todo, y a pesar de lo expresado, hay algunos estudios clásicos, aunque escasos, que se refieren a la historia de la sexualidad y que constituyen una base científicamente seria sobre la cual trabajar (26).

(24) AA.VV., Sexualidad y moral cristiana, Santiago-Barcelona, 1974, p. 235.

(25) Cf., por ejemplo, Schillebeeckx, E., El matrimonio, realidad terrena y misterio de salvación, Salamanca, 1968; Adnés, P., El matrimonio, Barcelona, 1980; Flórez, E., Matrimonio y familia, Madrid, 1995.

(26) Nos referimos señaladamente a la documentada obra de J.T. Noonan, "Contraception", Massachusetts, 1965, y al libro del teólogo belga L. Janssens, "Mariage et Fecondité", París 1967. Es sugerente que ambos estudios se publican a fines o inmediatamente después del Concilio 
Haciendo un esfuerzo de síntesis y de perspectiva histórica global, señalamos que en el periodo comprendido entre la Iglesia postapostólica y San Agustín, la enseñanza sobre la sexualidad (y el matrimonio) se elabora al calor de las luchas antignósticas y antimaniqueas. A continuación, San Agustín sistematizará su pensamiento, con fuerte aporte del estoicismo, el cual se transmitirá a la Escolástica medieval. Con Santo Tomás, se expandirá a toda la Iglesia permaneciendo muchos de sus planeamientos -asumidos por el Magisterio- inmutables hasta el Concilio Vaticano II. Este, al elaborar su enseñanza, tendrá en mente tanto la tradición de la Iglesia como los aportes de las ciencias humanas que tocan nuestra materia desde sus respectivos objetos formales, consideración que significará un notable esfuerzo por acercarse a una mayor "veridicción". Sin embargo, el Vaticano II dejará inconcluso un tema, hecho que queda plasmado en la conocida nota 14 del $\mathrm{N}^{\circ} 51$ de Gaudium et Spes (27). Esta situación pendiente, resuelta por la Encíclica Humanae Vitae (1968), será crucial en el objeto central de esta ponencia, es decir, en cuanto a los desafíos a la credibilidad de la Iglesia. Sobre lo expresado volveremos en el tercer paso del trabajo.

\section{Elaboración doctrinal hasta San Agustín.}

"El mundo de los tres primeros siglos es un mundo hostil frente a la procreación, un medio en el que se desenvuelven, frente a prácticas ascéticas rigoristas, el libertinaje, la promiscuidad masculina, la explotación sexual, el concubinato con las esclavas, el ejercicio mágico de la sexualidad misma. Todo esto no podía sino despertar la reacción de la ortodoxia cristiana" (28).

Noonan (29) presenta el siguiente cuadro sobre el ejercicio de la sexualidad en los primeros siglos de la vida de la Iglesia y que es necesario tener en cuenta para entender la elaboración doctrinal del período:

Vaticano II y en los años anteriores a Humanae Vitae (1968), la cual tiene como punto focal de análisis el tema de la fecundidad y el del control de la natalidad.

(27) “...Ciertas cuestiones que necesitan más diligente investigación han sido confiadas, por orden del Sumo Pontífice, a la Comisión pro Estudio de Población, Familia y Natalidad, para que, cuando esta acabe su tarea, el Sumo Pontífice dé su juicio. Permaneciendo así firme la doctrina del Magisterio, el santo Sínodo no pretende proponer inmediatamente soluciones concretas". Se sabe de los esfuerzos de Pablo VI para que el Concilio llegara a un acuerdo en la manera de armonizar el fomento del amor conyugal con una responsable transmisión de la vida (cf. GS., 51,1). De su puño y letra, incluso, introdujo diversos "modi" en el texto que debía ser votado. Al final, el Concilio condena, como era de esperar, aquellos caminos claramente contrarios a la enseñanza de la Iglesia, como son el aborto y el infanticidio, a los cuales cataloga como "crímenes abominables" (51,3). Sin embargo al referirse a otros caminos (¿los métodos para regular la natalidad?) acoge una fórmula de compromiso, para facilitar el acuerdo redaccional de lo que sería votado, entre una corriente más "naturalista" y otra más "personalista": "Cuando se trata, pues, de conjugar el amor conyugal con una responsable transmisión de la vida, la índole moral de la conducta no depende solamente de la sincera intención y apreciación de los motivos, sino que debe determinarse con criterios objetivos, tomados de la naturaleza de la persona y de sus actos..." (“...sed obiectivis criteriis, ex personae eiusdemque actum natura desumptis, determinari debet...) (Lo destacado es nuestro)

(28) AA.VV. Sexualidad..., o.c. 236

(29) Cf. Noonan, J.T., en la obra citada en la nota 26, pp. 57-58 
Izquierda:

Doctrina

1. La relación sexual, en cualquier forma, es necesaria para la salvación.

2. La relación sexual, de cualquier manera, es permisible para todos.

3. La relación sexual es permisible para cualquiera con tal que la procreación sea evitada.

Centro:

4. La relación sexual, para las mujeres, Sociedad romana convencional. solo es decente en el matrimonio; para los hombres, es permisible con sus mujeres, concubinas y prostitutas.

5. La relación sexual es permisible solo en el matrimonio; dentro del matrimonio no hay límites o propósitos específicos.

6. La relación sexual es permisible solo en el matrimonio, con tal que no sea contra la naturaleza.

Derecha:

7. La relación sexual es permisible solo en el matrimonio, y entonces, solo por la procreación.

8. La virginidad es preferida, pero la relación sexual es permisible en el matrimonio y solo por la procreación.

9. La relación sexual nunca es permisible.
Creyentes en toda experiencia posible.

Antinómicos estrictos.

Dualistas.

\section{Defensores}


Adnés (30) señala, también, que la enseñanza de la Iglesia, antes de San Agustín, se construye en reacción a los errores que combate. Los organiza en dos posiciones antitéticas: por una parte, las tendencias rigoristas representadas por:

- los encratistas: la castidad perfecta es ley, no consejo. Todo cristiano debe guardar la continencia perfecta. Al parecer, el Concilio de Gangres (hacia el 340) habría condenado la proposición, surgida en esos círculos, que señalaba que la única vía de salud eterna es la continencia y la masa de los cristianos se quedan en la vía ancha que lleva a la perdición (31).

- Los gnósticos, maniqueos y priscilianos, adherentes a una cosmología dualista.

- Los montanistas y novacianos, que señalan que las segundas nupcias son una especie de fornicación (32) o que Pablo solo ha tolerado el matrimonio y en virtud de lo cual ha dejado de ser pecado pero no por eso ha dejado de ser mancha (33).

Por otra parte, las tendencias laxistas que exaltan de tal modo el matrimonio que menoscaban la virginidad o que llegan a aceptar cualquier experiencia sexual como legítima. Entre ambos extremos los Padres del período propondrán su enseñanza, defendiendo la bondad del matrimonio contra los rigorismos que lo desprecian o derechamente lo condenan. A su vez, saldrán en defensa del estado virginal ante los laxismos que quieren negar su valor y justificar cualquier exceso sexual. En estas defensas, la Iglesia echará mano de argumentos escriturísticos, interpretados, la mayor parte de las veces, de modo alegórico, a reglas éticas judeo-estoicas, a concepciones antropológicas que no siempre logran articular de modo unitario la realidad espiritual y corporal de la persona. Añádase que los conocimientos sobre biología de la sexualidad, sobre fisiología de la fecundidad o de la unión conyugal son muy precarios, ingenuos o francamente erróneos. Todas estas "adherencias" filosóficas, culturales y "científicas" serán necesarias considerarlas a la hora de evaluar la veridicción de la enseñanza sobre la sexualidad en la época.

Entremos más de cerca en determinados aspectos y a través de ciertos autores representativos:

Algunas cartas del N.T. (34) nos dan testimonio de la presencia de corrientes de raigambre gnóstica en comunidades cristianas específicas: el "todo me es lícito" (1 Cor 6,12$)$ sería probablemente una objeción de los gnósticos antinómicos; en la misma línea iría la aceptación de un incestuoso en la comunidad de Corinto (1 Cor 5, 1-2). Este peligro de contagio hace reaccionar a Pablo denunciando que los que viven según la carne (Gál 5, 13) caen en toda clase de vicios como la fornicación, la magia sexual, la homosexualidad, etc.

(30) Cf. Adnés, P., o.c. 67-68.

(31) O.c. 67 , nota 4.

(32) Cf. Tertuliano en De monogamia 9; PL 2, 924

(33) Cf. Tertuliano en De Pudicitia 16; PL 2, 1012

(34) No corresponde en esta ponencia hacer un trabajo de análisis crítico de los textos que constituye una labor más propia de los especialistas en Sagrada Escritura. 
Con Clemente de Alejandría, en Oriente, tenemos una doctrina mucho más elaborada y a partir de las controversias con los herejes, algunos escritos (35) llegarán a tener un influjo importante en el pensamiento cristiano posterior. Por Clemente conocemos a Taciano quien, a la muerte de S. Justino, entra a liderar a los encratistas y condena el matrimonio como corrupción y fornicación. Por Clemente también sabemos de facciones antinómicas del gnosticismo que concebían a la mujer como propiedad común e, incluso, llegaban hasta la relación sexual después de la eucaristía en búsqueda de experiencias místico-religiosas, desde el momento que entendían que la unión sexual misma era el lugar de la comunión mística que les abría el reino de Dios. Ante ello, Clemente expresará que el matrimonio no es pecado y que ni Jesús ni Pablo lo han condenado (36); que la procreación es el fin principal del matrimonio (37) y la única razón de ser del acto conyugal porque, a su modo, la continencia debe guardarse también en el matrimonio (38). Reconoce, sin embargo, que la unión conyugal tiene lo que sería un fin secundario (según nomenclatura ulterior): "la ayuda que la mujer procura al hombre en el cuidado de la casa, las diversas necesidades de la vida, la enfermedad y la vejez. Una esposa honesta puede, además, tener una feliz influencia sobre su marido para inducirle la práctica de las virtudes cristianas. Ello es también parte de la misión de ayuda que Dios ha asignado a la mujer cerca del hombre" (39).

En Occidente hay manifestaciones, a su vez, de doctrinas extrañas y hasta contradictorias respecto al comportamiento sexual y al sentido del matrimonio: "Encontramos a los antinomianos como Basílides, Valentino y Saturnino, que afirman que el matrimonio y la procreación pertenecen al mundo de Satán (dualismo) y que la práctica lujuriosa de la sexualidad es indiferente moralmente para el hombre espiritual. Otros, como los carpocracianos y los cainitas, también afirman el carácter místicoreligioso de la unión sexual. Los gnósticos ascéticos, por otra parte, también se encuentran en Occidente (v.gr. los naacenos) afirmando que la nueva criatura es andrógina y que, por tanto, no hay necesidad del matrimonio ni de la generación de la prole. Su ideal es expresado en una especie de 'nudismo sagrado' y en la abstinencia de la unión sexual, ya que el coito no hace más que atar al mundo material" (40).

Sobre algunas de estas doctrinas tenemos los escritos de S. Ireneo (41) que nos permiten conocerlas y saber la línea de refutación que emplea: hace una fuerte condena del amoralismo completo en materia sexual (42) y al refutar a los gnósticos dirá que prohibir el matrimonio es injuriar al Creador que ha hecho los sexos diferentes para la propagación del género humano (43).

(35) Cf. especialmente Stromata y Paedagogo.

(36) Cf. Strom. 3,12; PG 8, 1177ss.

(37) El Pedagogo dirá: Qui autem matrimonio iuncti sunt, iis scopus est et institutum, liberorum susceptio. (Paedag.2,10; PG 8, 497).

(38) Cf. Strom. 3,7; PG 8, 1161.

(39) Adnés, o.c. 70.

(40) AA.VV. Sexualidad..., o.c. 240.

(41) Señaladamente Adversus haereses

(42) Cf. Adv.Haer. 1, 6,3; 1, 13,5; PG 7,508, 588, 592.

(43) Cf. o.c.1, 28,1; PG 7, 690. 
Frente a las concepciones heréticas sobre sexualidad y matrimonio, la ortodoxia recurrirá -como lo hemos expresado- al Nuevo Testamento (44) (cosa que también hacían los adversarios). Sin embargo, el sentido escatológico de muchos de sus textos y los explícitos sobre la virginidad no serán ayuda para un debate apologético. Recién en el s. IV, y de modo excepcional, S. Juan Crisóstomo acudirá a Efesios 5 para defender la dignidad del matrimonio (45). Es necesario reconocer, entonces, que en los escritos cristianos de la época amor y sexo no aparecen relacionados.

Para argumentar a favor de la dignidad del matrimonio y de la procreación y para atacar el libertinaje sexual, los Padres se apoyarán en una visión antropológica tomada del estoicismo, lo que marcará profundamente la enseñanza de la Iglesia prácticamente hasta los albores del Vaticano II. En el estoicismo encuentran una concepción de ley natural que no ha sido abolida por Cristo y reconocida explícitamente por Pablo (Rom 2, 14-15). Para el estoicismo, el mundo está estrechamente unido a Dios en forma de un panteísmo natural: "Es el mismo Dios al que llamamos Ceres en la tierra, Neptuno en el mar y que recibe otros nombres en otras partes del cosmos" (46). Este Dios es el alma del mundo, el cual, a su vez, es racional e inteligente. El mundo se gobierna por leyes inmutables que buscan realizar el bien y evitar el mal. Esta razón ordenadora se encuentra en todas partes, tanto en los dioses como en nosotros. Ahora bien, la moral estoica se basa en la sabiduría, la cual consiste en vivir virtuosamente que, en definitiva, es seguir la razón, eliminando las pasiones. La tarea ética es, entonces, descubrir en nosotros la naturaleza y actuar conforme al orden expresado en ella. La ortodoxia cristiana "bautizará" esta doctrina en la cual encuentran tantos aspectos aceptables para el cristianismo. Despojándola de sus adherencias panteístas, Ireneo, Clemente, Justino, Orígenes y luego Ambrosio y Agustín recurrirán al concepto de naturaleza para hablar de la sexualidad.

Según Noonan (47), la concepción de lo natural comprende los siguientes aspectos:

- Natural es lo exento de pecado. El ser humano descubre en sí mismo la ley de su naturaleza cuando se aparta del pecado y del error.

- Natural en el sentido de modelo universal que se encuentra tanto en los animales como en el hombre.

- Natural en el sentido de la estructura que podemos discernir en el cuerpo humano, o sea, la estructura biológica; la función más obvia captada por la razón es la expresión de la ley natural en el cosmos.

(44) Recurrir al Antiguo Testamento era mucho más difícil ya que era muy atacado por los gnósticos, llegando, algunos, a rechazar absolutamente su autoridad.

(45) De período posterior al estudiado hasta aquí, la concepción del matrimonio de este Padre es singular y, a veces, contradictoria. En efecto, en ocasiones señala que el matrimonio es secuela del pecado. Si Adán y Eva no hubiesen pecado, la propagación de la especie, como la de los ángeles, se hubiere asegurado por creaciones sucesivas. El matrimonio no es ya más que un remedio de la concupiscencia; su único fin es impedir la fornicación (cf. De virginitate, 14-19; PG 48, 543-547). Otras veces, habla del atractivo recíproco de los sexos, arraigado en la naturaleza misma. Aludiendo al mito platónico del andrógino dirá que por medio del hijo encuentran el hombre y la mujer su primera unidad y se destinan a formar una sola carne (Cf. In Epis.ad Colos., homilia, 12, 5-6; PG 62, 387-388).

(46) Cicerón en Tractatus de natura deorum 2,28 repitiendo lo que, según él, dicen los estoicos.

(47) Cf. Noonan, o.c. 74-75. 
Muchos elementos del estoicismo pasarán -en un esfuerzo de inculturación y en un clima de polémica con las corrientes heréticas- al acervo doctrinal de la Iglesia: el matrimonio se constituye a partir de una realidad evidente, cual es la distinción de sexos. Por tanto, la institución matrimonial encuentra su bondad y justificación en su ordenación a la procreación; el deseo sexual en cierta manera impide obrar según la razón. De ahí que, en lo posible, debe ser suprimido. Es verdad que el amor no está excluido en las obras de escritores cristianos pero no se le vincula con la misma unión sexual ni menos con el placer. La expresión de amor pertenece a otra esfera del matrimonio. De ahí expresiones como "los maridos deben unirse a sus mujeres moderadamente y solamente por razón de procrear hijos" (48) o "tener relación sexual por otra razón que procrear hijos es hacer injuria a la naturaleza" (49). El uso frecuente de metáforas sacadas de la vida rural o de la de los animales, empleadas por los estoicos, es recogido en escritores cristianos, especialmente para rechazar las uniones durante el embarazo. Si la matriz no admite un nuevo embarazo, es señal que no debe haber unión sexual, tal como el sembrador no siembra sino cuando la tierra lo permite (50). Orígenes, por su parte, expresará: "(hay algunas mujeres) que como los animales, sirven a la concupiscencia sin ninguna restricción; en verdad no las compararía a las bestias irracionales, porque las bestias cuando conciben saben que no deben seguir complaciendo a su compañero con su abundancia" (51). Queda claro que el rechazo a las relaciones conyugales en el embarazo se justifica porque el acto conyugal realizado en ese momento no es para la procreación, sino solamente para obtener placer, lo que, por el contexto, no sería bueno. Visión semejante se encontrará en la Didascalia (s. III) respecto a las relaciones en período de menstruación que se miraría como un uso irracional de la sexualidad y que favorecería el daño del feto si se concibe en ese momento.

A fines del s. III el gnosticismo ha perdido mucha de su influencia, aunque algunos de sus contenidos volverán a encontrarse en el maniqueísmo, doctrina que también ejerció atracción en ambientes cristianos por su comprensión religiosa del mundo y por poseer un mensaje de salvación. Ya que es suficientemente conocido, no entraremos en detalle en su doctrina. Baste recordar el profundo dualismo que preside su concepción religiosa, emparentándose, en ello, con el mundo gnóstico. Desde el momento que el primer hombre se origina en el mundo de las Tinieblas manteniendo una tenue conexión con la Luz, la moral maniquea se centrará en rescatar esa centella divina que hay en la persona. Los caminos para lograrlo son las comidas de vegetales (que contienen semillas) y la omisión de la relación sexual que lleva a la procreación desde el momento que es vista como un modo de aprisionar la luz: la semilla (el semen) contiene la luz. Es verdad que algunos de sus planteamientos extremos (por ej.: es bueno odiar el cuerpo, toda relación sexual es fornicación, el estado perfecto de los espirituales -pertenecientes al reino de la luz- es la continencia y la virginidad, la procreación es demoníaca) serán rechazados por la ortodoxia, pero un resabio de pesimismo, a partir de una antropología dicotómica, estará

(48) Stromata 3.11.71.4.

(49) Paedagogo 2.1093 .3$.

(50) Cf. íd. 2.10. 93.102.

(51) Orígenes, $5^{a}$ Homilía sobre el Génesis, citado por AA.VV, Sexualidad... o.c. 243. 
presente en la elaboración doctrinal ulterior. Llegará a manifestarse -en ocasionesen posiciones abiertamente heréticas tales como las doctrinas de los movimientos albigenses o cátaros condenadas por el Magisterio (52).

Además de los Padres ya nombrados, y con el ánimo de abrir el abanico de la comprensión doctrinal en el tema, mencionemos sucintamente el pensamiento de otros en Oriente y Occidente. Encontramos una policromía de planteamientos: algunos poco claros, hasta el punto que el pensamiento del autor es polemizado aun en el presente. Es el caso, por ejemplo, de S. Basilio. Para algunos investigadores, este Padre entiende el matrimonio como una simple tolerancia o condescendencia a la flaqueza humana. Otros destacan que en su obra se encuentran expresiones muy valiosas sobre los deberes de los esposos, vinculados por el amor (53). Otros padres tienen concepciones extrañas, por decir lo menos, sobre el origen de la sexualidad. Es el caso de Gregorio de Nisa: "Los sexos fueron creados distintos en previsión de la caída. La humanidad ideal, tal como existe en el pensamiento divino, en su designio eterno, es asexual y angélica. De no ser por el pecado, se hubiera propagado a la manera espiritual de los ángeles. Pero Dios previendo la mala elección de los hombres, los crea en un estado que es, por anticipación, consecuencia de su pecado. A su imagen mezcla algo de irracional; los viste de túnicas de pieles, añade el sexo a la naturaleza y la humanidad, divina por esencia, se desarrolla concretamente como una especie animal" (54). La consecuencia de lo expuesto es sorprendente: la vida sexual, la generación, el matrimonio sería algo sobreañadido a la naturaleza humana y consecuencia del pecado (55). Si la vida sexual es una de las pieles con que Dios ha envuelto la naturaleza pecadora, el matrimonio es, entonces, la primera de esas túnicas de las cuales es necesario desprenderse para volver a ser imagen de Dios (56). Gregorio Nacianceno aparece con una doctrina bastante equilibrada entre el matrimonio y la virginidad: "El matrimonio es bueno, pero no puedo decir que sea mejor que el estado de virginidad. Por lo demás, la virginidad no sería tan excelente si no sobrepujara precisamente a una cosa de suyo buena" (57). En la misma obra llama a que los dos estados estén unidos en el Señor a fin de que cada uno sea ornamento del otro.

San Ambrosio ha escrito especialmente en relación con la virginidad exaltándola fuertemente, lo que lo ha llevado a un cierto menosprecio del matrimonio (58), sin llegar, ciertamente, a una condenación. Afirma que la mujer ha sido dada al hombre con miras a la procreación (59), comprensión de la mujer que será ampliamente aceptada en la época. Con todo, para ser justo con su pensamiento, tiene páginas hermosas sobre el amor mutuo de los esposos (60).

(52) Cf., por ejemplo, el $2^{\circ}$ Concilio de Letrán en 1139 que condena a los que desprecian y rechazan "la unión conyugal legítima" (contra los cátaros, que en la época se oponían al matrimonio "no sin cierta violencia" cf. E. Schillebeeckx, o.c., p. 312).

(53) Cf. S. Basilio, Moralia 73,3; PG 31, 852.

(54) Adnés, o.c. 73-74.

(55) Cf. Gregorio de Nisa, De hominis opificio 17; PG 44, 188-189.

(56) Cf. De Virginitate 12; PG 46, 373-376.

(57) Oratio 37; PG 36, 293.

(58) Cf. De virginibus 1; PL 16, 195-196.

(59) Cf. De paradiso 10; PL 14, 298.

(60) Cf. Hexamerón 5,7; PL 14,214. 
Finalmente, una referencia a San Jerónimo. Con frecuencia, el polemista apasionado ha prevalecido sobre el teólogo y ha marcado, con ello, una línea doctrinal de fuerte rigorismo: "En su controversia con Joviniano recoge algunos de los argumentos más discutibles de Tertuliano. Si es bueno, como dice San Pablo, no tocar mujer (1 Cor 7,1$)$, se sigue que es malo tocarla. El matrimonio no pasa de ser un mal menor, solo tolerado para evitar otro mayor; solo se justifica por el peligro de la fornicación... El marido que se abstiene de la unión sexual honra a su mujer; el que la ama con demasiado ardor comete un adulterio... Sostiene que el cumplimiento del acto sexual debe apartar de la comunión un día o dos" (61).

En conclusión, la enseñanza sobre sexualidad y matrimonio, en el período, se va configurando al tenor de planteamientos gnóstico-maniqueos que, con frecuencia, se rechazan pero que van dejando "huellas" culturales. Además, el recurso frecuente a una antropología de sello estoico hará difícil articular una visión unitaria sobre el sentido del matrimonio -como lo veremos a continuación- y tenderá un manto de sospecha sobre el ejercicio de la sexualidad que no contemple la procreación.

\section{San Agustín}

Es indudable que el pensamiento de este Padre en nuestro tema es el más elaborado, extenso y novedoso. Escribiendo de la materia en sí misma, polemizando con adversarios o realizando comentarios bíblicos (62) va configurando una doctrina que permite nominarlo como el Doctor del matrimonio cristiano (63). "Lejos de ser condenable, como querían ciertos herejes, el matrimonio es bueno. Fue instituido y bendecido por Dios al comienzo del mundo, y levantado luego por Cristo a la función sublime de representar su propia unión con la Iglesia. Así alabar la virginidad no es reprobar el matrimonio. Y hasta se hace más bello elogio de la virginidad cuando se le pone por encima de un estado, que es bueno en sí mismo" (64). Dicha visión positiva tiene su base en los tres bienes que conlleva el matrimonio: proles, fides, sacramentum.

Para los efectos de esta sinopsis histórica, nos interesan algunos aspectos de su comprensión del matrimonio y su manifestación conexa, cual es la relación sexual. Sus escritos revelan una cierta concepción dualista, la cual tiene su punto de arranque en una pretendida incompatibilidad entre el amor de los esposos, por una parte, y el ejercicio de la intimidad con el placer que lo acompaña, por otra. Esta dicotomía pone de relieve muchas de sus influencias filosóficas y adherencias culturales que marcarán, por extensos siglos, la enseñanza eclesial del matrimonio y el sentido de la sexualidad.

En efecto, hay dos concepciones yuxtapuestas en el pensamiento agustiniano, según las obras que se estudien: el matrimonio basado en la diferenciación biológi-

(61) Adnés, o.c. 77, donde el autor va citando ciertas epístolas de S. Jerónimo, y especialmente su obra "Adversus Jovinianum". Algunas de sus afirmaciones sobre el matrimonio causaron escándalo en Roma, viéndose obligado a defenderse y atemperar, en parte, su pensamiento.

(62) Mencionamos varias de sus obras y opúsculos al respecto: De Continentia, De sancta virginitate, De bono viduitatis, De nuptiis et concupiscentia, De bono coniugali, De Genesi ad litteram, Contra Faustum, Contra Iulianum Pel., De coniugiis adulterinis.

(63) Así, Adnés, o.c.78

(64) O.c. ibíd. 
ca de los sexos y el matrimonio basado en la sociabilidad humana. Si el matrimonio está fundado en la distinción sexual del hombre y de la mujer y no existiendo esta sino por razones de tener hijos, es claro que el matrimonio como institución ha sido creado por Dios para la procreación y educación de la prole (bonum prolis). En diversos textos se encuentra esta misma idea. Así, al interpretar Gn., 2,18 (65) dirá: "Cuando se pregunta para qué clase de ayuda del varón es hecho aquel sexo (la mujer), a mi parecer solamente a causa de la prole, para que a través de ella la tierra se llene" (66). La misma etimología de la palabra matrimonium es entendida, por Agustín, como un indicio que la "mujer debe casarse no por ninguna otra causa que la de ser hecha madre" (67). Es, sin embargo, en su controversia con los maniqueos donde explaya su pensamiento: “¿No son ustedes los que solían advertirnos que nos cuidáramos, tanto como pudiéramos, del tiempo después de la purificación de las reglas, cuando una mujer está preparada para concebir, y en este tiempo refrenar la relación, no sea que un alma quedara implicada en la carne? De esto se sigue que ustedes consideran el matrimonio no para procrear hijos, sino para saciar la concupiscencia. El matrimonio, como lo proclaman también las tabulae nuptiales, une al varón y a la mujer para procrear hijos. Quienquiera que diga que procrear hijos es un pecado peor que unirse en cópula, prohíbe por lo mismo el matrimonio; y hace a la mujer no esposa sino prostituta, la cual cuando le han sido dados algunos presentes, se une al hombre para satisfacer su concupiscencia. Si hay esposa, hay matrimonio. Pero no hay matrimonio cuando la maternidad ha sido evitada; porque entonces no hay esposa" (68). En Contra Faustum expresará: "Por eso, la ley eterna, es decir la voluntad de Dios creador de todas las criaturas, tomando consejo para la conservación del orden natural, no para servir el deseo, sino para cuidar la preservación de la raza, permite que el placer de la carne mortal sea liberado de la razón en la cópula, solamente para propagar la especie" (69). Estamos ante un argumento de innegable sabor estoico donde se manifiesta una profunda desconfianza frente al placer en general y al sexual en particular. Si para la moral estoica nihil fac propter solam delectationem cuanto más en la moral cristiana que debe superar las exigencias de una ética pagana. Solo el acto sexual originado en una intención procreativa es honesto y bueno. De lo contrario es, al menos, un pecado venial, una especie de adulterio leve porque no se han traspasado los límites de la fidelidad (70). Ahora bien, como, para Agustín, el dominio del placer por parte de la razón es difícil en este orden de cosas (71), no creemos exagerar al decir que en su teología hay una especie de presunción de falta moral leve en las relaciones íntimas conyugales.

Para comprender mejor este punto y sus ulteriores consecuencias doctrinales volvamos a la doctrina de los bienes del matrimonio. Para Agustín hay dos clases de bienes: aquellos que son dignos de ser buscados por sí mismos como serían, por

(65) Agustín, como es claro, no posee los instrumentos de las ciencias exegéticas contemporáneas que se aplican, hoy, a los textos de la Sagrada Escritura.

(66) De Gen.ad litt. IX,5, 9; PL 34, 396.

(67) Contra Faustum XIX, c.26; PL 42, 365.

(68) La moral de los maniqueos 18,65; PL 32, 1373.

(69) Contra Faustum 22,30; PL 25, 624.

(70) Cf. De bono coniug. 6 y 11; PL 4, 377-378 y 381-382.

(71) Cf. íd. 15; PL 40, 384. 
ejemplo, la sabiduría y la amistad. Otros que son medios en vista de la finalidad para la cual han sido creados, como es el caso del comer, el beber (72) y la relación sexual. Obrarán correctamente, ante este último tipo de bienes, aquellos que los usan para alcanzar la finalidad natural que tienen. Queda claro, que referida a la relación sexual aquella es la procreación. Solo así se obra conforme a la naturaleza. Es en su polémica con los pelagianos donde Agustín profundiza el sentido teológico del placer, relacionándolo con el pecado y la concupiscencia: "Si Adán no hubiera pecado, no habría concupiscencia en la generación. En el deseo sexual hacemos la experiencia de la ley de los miembros que lucha contra la ley de la razón, interpretando así Rm 7, 23 y Gál 5,17 . Llama al deseo sexual a veces 'ley del pecado', porque incita a él; 'pecado' en tanto que es su fruto o arrastra a él; o 'pena del pecado' en el sentido de que el hombre está condenado en él a experimentar la desobediencia de sus miembros. Por tanto, es un mal o enfermedad que no hay que imputar al matrimonio, sino al pecado. Por eso, S. Agustín defenderá contra los maniqueos la bondad del matrimonio; contra los pelagianos, que la concupiscencia es mala; en el medio estará la relación sexual que es mezcla y deberá ser justificada" (73).

A la luz de lo expuesto, será lógico que todo viciamiento, encaminado a impedir la procreación se opone al orden natural: así, el acto interrumpido de Onán (74), los venena sterilitatis (drogas anticonceptivas) (75) y otros comportamientos en la misma línea.

Sobre la segunda concepción del matrimonio, basada en la naturaleza social de la persona, tenemos el aporte de Bono coniugali que en su introducción manifiesta: "Puesto que cada hombre es parte del género humano y la naturaleza humana es algo social y tiene también la fuerza y el bien natural y grande de la amistad, por eso quiso Dios fundar a todos los hombres en uno, para que en sociedad se tuviera no solo la similitud del género, sino también el vínculo de la comunidad. La primera unión natural de la sociedad humana es la del hombre y de la mujer, a los cuales no creó Dios como singulares ni juntó como extraños, sino que a ella la creó de él, señalando también la fuerza de la unión en el costado de donde aquella es formada. Se juntan, entonces, por los costados aquellos que caminan y miran juntos. Consecuente con esta, tenemos la conexión de la sociedad en los hijos, que son fruto honesto, no de la sociedad del hombre y de la mujer, sino de la unión sexual. La unión de marido y mujer podría darse aun sin tal unión como una unión fraterna y amistosa" (76).

Aquí Agustín destaca la amistad espiritual, la "relación interpersonal de amor" (para decirlo en lenguaje contemporáneo) entre esposo y esposa. En el orden de la creación, esa fraterna societas tiene su primera manifestación en el matrimonio.

(72) En las Confesiones, Agustín dirá que el alimento hay que tomarlo del mismo modo que se toma un remedio. "Pero cuando paso de la opresión de la necesidad al bienestar del aplacamiento, es precisamente en esta transición donde me acecha el lazo de la concupiscencia. Pues la misma transición es placer, pero la necesidad nos obliga a seguir este camino y no otro" (Confes. X, 31, 44).

(73) AA.VV. Sexualidad... o.c. 249-250.

(74) Cf. De coniug.adulter. II, c.12, nº 12; PL 40, 479.

(75) Cf. De nuptiis et concupisc. I, c.15, nº 17; PL 44,423.

(76) De bono coniug. 1,1; PL 40, 373. 
Dicha comunicación tiene su valor propio, de tal modo que en este plano y permaneciendo en él (amistad) los esposos no están obligados a buscar la procreación. Parece claro que en la trilogía de bienes, Agustín pone en primer lugar el bonum prolis. Sin embargo, cuando no se tiene en cuenta la procreación o ella no es posible, el bonum fidei basta para asegurar el valor del matrimonio. Tal es el caso de las personas ancianas (77) o de los que han optado por renunciar a la intimidad sexual conyugal, como María y José (78) permaneciendo en una unio animorum. Es claro que esta unión espiritual, para Agustín, será más fuerte en la medida que los esposos se aparten de la "atracción de la carne", optando por la continencia absoluta, nivel máximo del bonum fidei. A la luz de esta opción se entenderá mejor el bonum sacramenti, que es la alianza de las almas en la caridad, y cuyo vínculo es indisoluble como el de Cristo y la Iglesia.

Queda claro, al concluir, la yuxtaposición de dos concepciones matrimoniales que no logran unificarse en una sola definición. La procreación no es fruto de la sociedad conyugal sino del acto sexual, hasta el punto que puede darse matrimonio sin relaciones genitales, como procreación sin matrimonio. Se comprende, entonces, que a la base de esta reflexión hay un fuerte dualismo entre el amor espiritual y la sexualidad. Son dos órdenes separados que se mantendrán así, en la elaboración doctrinal -como veremos-, hasta el Vaticano II.

\section{Elaboración doctrinal desde S. Tomás hasta Pío XII}

La concepción dualista del matrimonio de Agustín es continuada, con categorías propias, en el pensamiento de Santo Tomás y de la Escolástica en general, a través del concepto y contenido de la ley natural (79). En efecto, en la elaboración tomista dicha ley comporta tres niveles: uno común con todos los seres vivos que los lleva a conservar la existencia y dos niveles propios que se dan en el ser humano: el primero, sin embargo, tiene por contenido aquello que es común con los seres vivos del reino animal (por ejemplo, la tendencia que nos impulsa a la unión sexual). El segundo sería el nivel específicamente humano que brota de nuestra naturaleza racional, en virtud del cual la persona se abre a Dios y a la comunidad con el resto de los hombres. Es necesario dejar en claro que estos tres niveles no aparecen como realidades disgregadas en nuestra especie sino unificadas en la razón humana que las regula y dirige.

La continuación del dualismo, al cual aludimos, se expresa en las categorías de ordo naturae (orden genérico) y ordo rationis (orden específico), los cuales forman parte de la ley natural. El primero es un orden inmutable, inquebrantable y es común con todos los animales. En efecto, Tomás acude para explicarlo, a la definición de Ulpiano: quod natura omnia animalia docuit. Ahora bien, este orden está determinado por la realidad biológica y ha sido establecido directamente por Dios, creador y autor de la naturaleza. Al trastrocar ese orden, el ser humano está alterando las

(77) Cf. íd. 3; PL 40, 375.

(78) Cf. De nuptiis et concupisc. 1,11,12; PL 44,420-421.

(79) Hay aportes tomasianos en temas matrimoniales que son muy valiosos y que indicaremos en páginas ulteriores y en la tercera parte del trabajo. 
relaciones con Dios y obrando contra naturam. El nivel explicado, en cuanto es un orden prior et stabilior, es el basamento sobre el cual se edifica el nivel siguiente.

Este nivel es el llamado ordo rationis, específico y exclusivo de nuestra especie en cuanto ser espiritual, por medio del cual -como lo dijimos- nos vinculamos con Dios y establecemos relaciones de convivencia con otras personas. La autoría de este orden pertenece al mismo hombre llamado a descubrir el ordo naturae, a respetarlo y realizarlo de modo consciente y libre, según las diversas circunstancias históricas. Es lo que S. Tomás llama el ordo rationis rectae (80). Por tanto, este nivel específicamente humano tiene dos funciones: por una parte, reconocer el orden natural, y por otra, inventar -pero en el respeto a ese orden- todo el resto que depende de la estricta y exclusiva racionalidad (disponere secundum quod convenit). Esta "invención respetuosa" es lo formal de la ley natural en nosotros.

Las distinciones expuestas calzan adecuadamente con la comprensión del matrimonio en la teología tomasiana. En efecto, tenemos al matrimonio basado en la ley natural genérica o perteneciente al ordo naturae y el matrimonio basado en la ley natural específica o perteneciente al ordo rationis. El primero tiene por finalidad la procreación, en cuanto la distinción de los sexos -como ocurre en el resto de los animales- tiene por objeto la generación de nuevas vidas. La estructura biológica (órganos genitales y sus funciones) "va diciendo" el para qué del acto sexual (coito) tanto en el ser humano como en los animales. Así lo dispuso el Creador según el orden de la naturaleza. El matrimonio y los actos sexuales dentro de él están destinados al bien de la especie (propagar la vida) así como el comer y el beber están para bien del individuo (conservarse en la vida). Estos actos serán honestos cuando no se aparten de la finalidad para la cual fueron establecidos. Es lógico, entonces, que un acto sexual puesto por otra razón que la de transmitir la vida (aunque se pida o se dé para evitar la incontinencia de la otra persona) es una falta moral, al menos venial, en cuanto desordena el orden exigido por la ley natural en este nivel (81). Unamos a lo expresado, la biología ingenua que maneja la Escolástica, propia de la época: el semen es una semilla escasa que hay que cuidar y que contiene la vida en germen (82). Se sigue que el abuso en esta materia constituye un cuasihomicidio. Nada se dice, en el período, del abuso que pudiera ocurrir con el comportamiento sexual de la mujer, desde el momen-

(80) "Santo Tomás contará con estos materiales (la concepción de Ulpiano y una comprensión más racionalista de Cicerón), acentuando en algunos pasajes de su obra una concepción más biologicista de la ley natural; en otros será la recta ratio que participa del plan que Dios tiene sobre el universo. Esta 'identificación' entre una corriente más naturalista y otra más personalista será fuente de conflictos interpretativos que han llegado hasta hoy en el debate teológico. Sin embargo, el texto más clásico y decisivo se encuentra en la Suma Teológica I-II, q.91, a.2. donde señala que 'la ley natural (en el hombre) no es más que la participación de la ley eterna en la criatura racional'. En este texto, Santo Tomás se inclina, entonces, por la línea 'ciceroniana' estableciendo que la ley moral natural es aquella recta ratio que nos induce al bien y a la verdad, privilegiando, así, su carácter personal, diferente al resto de los seres creados. La finalidad de esta ley, que es la razón inclinada naturalmente hacia el fin del hombre, es discernir lo bueno y lo malo". Romo, W., La conciencia moral, mediación personal de salvación, en Teología y Vida 12, XLII (2001), pág.183, nota 36.

(81) A una conclusión semejante había llegado S. Agustín desde su propio razonamiento.

(82) "Inordinatio circa emissionem seminis est circa vitam humanam in potentia proxima". De malo, 15,2; Cf. Summa contra Gentes 3, 122. 
to que no se sabe de la existencia del óvulo (83) y la matriz femenina es entendida como una "tierra fértil" donde germina la semilla depositada por el varón, único que posee ese principio activo para transmitir la vida. La mujer, en este nivel, es "ayuda adecuada" del varón para tener hijos, sin pasarse por la mente que pudiera tener un papel activo en su propia vida sexual.

Las aplicaciones casuísticas de S. Tomás en la moral conyugal son mucho más precisas que en S. Agustín y provienen de una rigurosa lógica: todo pecado es contra naturam en cuanto se opone a la naturaleza racional de la persona. Sin embargo, ya que el ordo naturae es anterior al ordo rationis (y este se construye sobre aquel que es prior et stabilior) se sigue que la masturbación, por ejemplo, es más grave que el adulterio y que el mismo incesto porque la primera atenta contra la ley natural genérica. En la misma línea de pecados contra naturam se ubica a la homosexualidad y la bestialidad (84). En cambio, la fornicación, el adulterio, el incesto son pecados secundum naturam, en cuanto permiten -al menos- la generación de la vida. Esta conclusión que nos parece chocante a nuestra reflexión no es más que la aplicación lógica de la manera de ver los niveles de la ley natural aplicados al mundo del comportamiento sexual.

El matrimonio, basado en la ley natural específica (ordo rationis) nos lleva al encuentro de amistad, a la 'asociación' del hombre con la mujer: "natura movet ut sit quaedam viri ad mulierem associatio, in qua est matrimonio" (85). Según este segundo sentido, los esposos están llamados a colaborar recíprocamente en las tareas familiares, a cultivar una relación de amistad y de ayuda (amicitia et mutuum obsequium). Todo ello proviene del orden de la razón, que supone respetado el otro orden, y se expresa de manera mutable en sus expresiones, modelándose según las circunstancias y las costumbres de los pueblos. Así como el primer orden nos llevaría al matrimonio ut est in officium naturae, este nos orienta al matrimonio ut est officium civilitatis. Quedan sentadas, de este modo, las bases para la ulterior elaboración de la enseñanza de los fines del matrimonio (86): el primario, la procreación y educación de la prole, primario en cuanto proviene del ordo prior et stabilior establecido por Dios y el secundario que es la amistad y ayuda mutua, dimensiones fundadas en la naturaleza social de los esposos, orientadas al servicio del fin primario y, de alguna manera, basadas en un ordo supperaditus. Se llega, así, aunque por otros razonamientos, a la misma visión de la etapa anterior: una dicotomía en la comprensión del matrimonio que se mueve en "dos pisos" incomunicados. Ello se origina en que "el orden biológico de la relación conyugal no es relacionado con la comunión indivisible de las personas en el amor. En otras palabras, continúa la tradición agustiniana de que el acto sexual es pura y exclusivamente acto de la naturaleza biológica como el comer y el beber" (87).

(83) Este se descubre, recién, en 1827 por Ernesto von Baer.

(84) Cf. Summa Theologica II-II 154, 12.

(85) Suppl. 41,1.

(86) Doctrina recogida oficialmente en el Código de Derecho Canónico de 1917 que en el canon 1013 consagra los dos fines del matrimonio.

(87) AA.VV., Sexualidad... o.c. 256. 
Janssens (88) expresa que tímidamente fueron abriéndose paso, en los siglos posteriores, algunas ideas que otorgaron una mayor benignidad en el finis operantis (89), es decir, en la intencionalidad subjetiva de los cónyuges. Así, cita la tesis de Le Maistre (90) que enseña que "no es cierta la necesidad absoluta y explícita de la procreación como única y exclusiva causa de licitud del acto conyugal". En buenas cuentas, no se atentaría contra la castidad conyugal si hubiera otros motivos, además de la procreación, al realizar el acto sexual conyugal. Las Institutiones Theologiae Moralis, que la historia de la teología moral considera los primeros manuales de moral católica de la época moderna, aceptarán esta apertura en las intenciones de los esposos, no solo por peligro de incontinencia del otro cónyuge sino por peligro para consigo mismo. Además, entienden el texto de $1^{\text {a }}$ Cor 7, 5-6 de manera diferente a Agustín y Jerónimo. El hoc autem dico secundum indulgentiam del v.6 no lo interpretan como perdón de un pecado sino simplemente como lo que expresa el texto: la declaración de licitud de las relaciones conyugales. Se dará otro paso adelante al tocarse el tema del placer. Cuando este se busca en sí mismo ¿puede también ser motivo subjetivo (finis operantis) para legitimar la relación sexual entre los esposos? La respuesta ya podía encontrarse en algunos planteamientos de S. Tomás que manifiesta que el placer (la delectatio) acompaña la realización de un acto bien hecho y que es más fuerte en la medida en que ese acto sea más importante (91). Por tanto, buscar el placer, en ese contexto, no va contra la voluntad del Creador, siempre que se respeten los límites de la templanza y que no sean excluidos "positivamente" los fines intrínsecos del acto sexual y del matrimonio, es decir, su ordenación procreativa. Va quedando claro, entonces, que progresivamente se introducen algunos cambios en la comprensión de la sexualidad y del matrimonio, siendo uno de los más significativos el afirmar que no es necesaria una intención explícita procreadora en cada unión conyugal.

Entramos al s. XIX donde se empieza a reconocer, cada vez con más fuerza, la necesidad de fomentar el mutuo amor conyugal, de modo que este no se manifiesta solo en las caricias sino alcanza a la intencionalidad con que los esposos realizan el acto conyugal mismo.

Los descubrimientos de Ogino y Knaus, que culminaron en 1930, otorgaron las bases científicas para la llamada "continencia periódica" y abrieron un nuevo frente de reflexión en la teología moral. La sola consideración de los nuevos aportes de las ciencias biológicas significó un paso decisivo en la búsqueda de una mayor veridicción en la enseñanza sobre el comportamiento sexual. Este paso, sin embargo, no estuvo exento de polémicas y cuestionamientos. Algunos moralistas estimaban que "en la medida en que se admitía la continencia periódica, ipso facto se aceptaba también que en sus

(88) Cf. o.c. en nota 26.

(89) La misma distinción ya mencionada de fin primario y fines secundarios tuvo en consideración otra distinción entre finis operis y finis operantis. El primero se refiere al contenido ontológico de lo que se hace (de la obra) y eso está dado por la naturaleza objetiva del acto (S. Tomás diría por el ordo naturae). El segundo mira a la subjetividad del que realiza la obra, moviéndose en el plano de la intencionalidad o motivación personal, que puede o no coincidir con el finis operis.

(90) Janssens, L., o.c. 63, donde presenta el pensamiento de M. Le Maistre, teólogo de fines del s. XV en su obra Eximii doctoris parisiensis magistri Martín Magistri de temperantia liber, París 1490 et 1511 .

(91) Cf. Summa Theologica I-II, 31, 1 ad.1 y I-II, 31, 3. 
uniones sexuales los cónyuges excluyeran positivamente la procreación de su intención" (92). Llegamos, así, a la Encíclica Casti Connubii de Pío XI (1931) donde se vuelve a presentar el dualismo agustiniano-tomista pero se reconoce que las relaciones sexuales son lícitas más allá de la exigencia procreativa sobre la base de motivos subjetivos que la encíclica ubica dentro de los fines secundarios del matrimonio (93). La última frase de la cita de Casti Connubii transcrita en nota es un verdadero "clásico" de la teología moral de la época: "dummodo salva semper sit intrínseca illius actus natura, ideoque eius ad primarium finem debita ordinatio”. Lo manifestado implica una condenación de la anticoncepción (artificial) apoyándose en la ley natural, en la Sagrada Escritura y en la tradición de Agustín y Tomás de Aquino. El argumento es siempre el mismo, supuesto que se interprete viciar la "naturaleza del acto" en el sentido del acto conyugal en cuanto a su ordo naturae (Tomás) o en cuanto al matrimonio fundado en la distinción de sexos (Agustín). Viciar con prácticas anticonceptivas este acto es un pecado contra la naturaleza. Es claro que toda la fuerza de la argumentación reside en que solo es admitida la finalidad procreadora de las relaciones sexuales. La expresión de amor que pueden contenerse en aquellas es algo supperaditus y secundario.

Concluyamos con una breve referencia a un aporte de Pío XII que no se ha destacado lo suficiente (94). En él se hace eco de una concepción personalista del matrimonio y de la intimidad conyugal, propia de la cultura que se va abriendo paso en los años siguientes a la Segunda Guerra Mundial: "El acto conyugal, en su estructura natural, es una acción personal, una cooperación simultánea e inmediata de los cónyuges que, por la naturaleza misma de los agentes y la propiedad del acto, es la expresión del don recíproco que, según la palabra de la Escritura, efectúa la unión en una carne" (95). El texto se acerca, indudablemente, a superar el dualismo clásico de tantos siglos y preanuncia ya la teología del Vaticano II, donde el amor conyugal no se considerará como un fin secundario o un finis operantis de la intimidad sexual sino que formará parte del mismo finis operis, es decir, de la ontología de significación de la relación esponsalicia.

\section{DESAFÍOS CONTEMPORÁNEOS ACERCA DE LA CREDIBILIDAD DE LA ENSEÑANZA DE LA IGLESIA SOBRE LA SEXUALIDAD}

Juan XXIII en el discurso de inauguración solemne del Concilio Vaticano II entrega la clave de comprensión para afrontar estos desafíos, no solo referidos a

(92) AA.VV., Sexualidad... o.c. 258

(93) "Ni hay que decir que obren contra el orden de la naturaleza los esposos que hacen uso de su derecho de modo recto y racional, aunque por causas naturales ya del tiempo, ya de determinados defectos, no pueda de ello originarse una nueva vida. Hay, efectivamente, tanto en el matrimonio como en el uso del derecho matrimonial, otros fines secundarios, como son, el mutuo auxilio, el fomento del amor mutuo y la mitigación de la concupiscencia, cuya prosecución en modo alguno está vedada a los esposos, siempre que quede a salvo la naturaleza intrínseca de tal acto y, por ende, su debida ordenación al fin primario..." (Dz. 2241) (El destacado es nuestro).

(94) No nos referimos aquí a otros aportes de este Pontífice en materia de matrimonio que no tocan el centro de interés de esta ponencia.

(95) Pío XII, Discurso a las matronas italianas, CEDP (Colección de Encíclicas y Documentos Pontificios (AC, España), Madrid, 1962, p.1711 (Los destacados son nuestros). 
nuestro centro de interés, sino a todos aquellos que plantea la cultura moderna: "Una cosa es el depósito mismo de la fe, es decir, las verdades que contiene nuestra venerada doctrina, y otra la manera como se expresa; y de ello ha de tenerse gran cuenta, con paciencia, si fuese necesario, ateniéndose a las normas y exigencias de un magisterio de carácter prevalentemente pastoral" (96). Es claro, a nuestro juicio, que la manera como se expresa una enseñanza incorpora la preocupación por la credibilidad de ella y este interés tiene que ser un "dato" permanente en la elaboración doctrinal de futuro. Aquí ya tenemos un primer y fundamental desafío. Se trata, en el fondo, de "tomar en serio" los contextos culturales que están presentes en los receptores de una enseñanza para que esta pueda ser creíble (97). "Decir verdad" acerca de una doctrina no es simplemente proclamarla sin importar el mundo cultural del destinatario. Si este no se toma en cuenta, se corre el riesgo no solo que no sea comprendida, sino que se cuestione su credibilidad. Es lugar común decir en moral católica que la persona debe actuar conforme a su conciencia pero debidamente iluminada (por el Magisterio). Sin embargo, surge una pregunta crucial: ¿cómo ilumina ese magisterio las conciencias de las personas para que estas "experimenten esa iluminación"? Es de temer que, en ocasiones, la proclamación doctrinal esté tan desfasada de la cultura del receptor que aquella simplemente "resbale" y no se produzca el efecto iluminador que se busca. No bastaría decir que nos encontramos ante una "conciencia invenciblemente errónea" y que, por tanto, la conducta discrepante de esa persona con la enseñanza la hace inculpable o subjetivamente defendible. Hoy asistimos a un fenómeno eclesial relativamente frecuente: no es que el cristiano desconozca lo que enseña la Iglesia (ciertamente que a veces eso ocurre) sino que no experimenta la vinculación de su conciencia con esa doctrina que recibe y que conoce. ¿Estamos ante una contumacia y rebeldía increíble? ¿Ha llegado a tanto el orgullo de esa persona que se permite discrepar de lo que le enseñan sus Pastores? ¿Es el más absoluto subjetivismo el que se ha entronizado en esos cristianos? Para algunos la clave de respuesta está precisamente en esa contumacia, orgullo y subjetivismo. Es lo que expresábamos al comienzo del trabajo: la ratione peccati. ¡Puede ser!... pero ¿no cabría alguna otra explicación, especialmente cuando las distancias entre la moral proclamada y la moral vivida son tan significativas y masivas? Es posible que la manera como se expresa (para decirlo en términos de Juan XXIII) esa enseñanza esté en cuestión.

¿Qué está pasando hoy, según algunos datos culturales, con la significación de la sexualidad? Vidal (98) manifiesta que "se ha pasado de una comprensión de la

(96) Juan XXIII, Discurso pronunciado el 11 de octubre de 1962 en la Basílica Vaticana con ocasión de la inauguración solemne del Concilio Ecuménico Vaticano II, reproducido en Concilio Vaticano II, Constituciones. Decretos. Declaraciones, Madrid, 1975, p.1033 (El destacado es nuestro).

(97) Esos contextos culturales se descubren, no desde el depositum fidei sino desde los aportes que nos pueden entregar disciplinas como la antropología cultural, la sociología, la psicología, las ciencias biomédicas, la sexología, etc.

(98) El autor presenta en su libro Moral del amor y de la sexualidad, o.c., un interesante aporte al referirse a la sexualidad en el mundo actual (cf. pp. 81-93) donde comenta la 'erotización' de la sociedad actual, la 'ganancia' en extensión y la pérdida en calidad de la sexualidad, la "revolución sexual” proclamada por autores como W. Reich y otros, la sexualidad como 'distracción', como 'consumo', como 'factor de represión social', como 'falsa sacralización', la nueva situación sociocultural de la juventud respecto a la sexualidad, la nueva manera de enfrentar el noviazgo, etc. 
sexualidad como 'genitalidad' a la sexualidad como 'dimensión integral' de la existencia humana (99), de la sexualidad como 'función procreativa' a la sexualidad como 'expresión o lenguaje' de la persona, de la sexualidad como 'placer' a la sexualidad como 'comunicación interpersonal', de la sexualidad como 'bien referido al matrimonio' a la sexualidad como 'valor autónomo'. Estas variaciones en la comprensión de la sexualidad han tenido y seguirán teniendo grandes repercusiones en los comportamientos previos al matrimonio" (100).

La doctrina del Vaticano II sobre sexualidad y matrimonio (101) ha empezado a enfrentar estos desafíos y ha tenido en cuenta, ciertamente, las voces de nuestro tiempo, al plantear su enseñanza, asumiéndolas críticamente, es decir, discerniendo lo que hay de positivo en ellas y lo que tienen de insuficientes, exageradas o unilaterales. También le ha interesado el modo como necesita expresarse esa doctrina. Ha recurrido, entonces, al aporte de las ciencias sociales en un verdadero esfuerzo de diálogo interdisciplinar. Resultado de ello ha sido destacar el amor conyugal como una dimensión central del matrimonio. Lo expresado, sin embargo, puede parecer poco novedoso. ¡Tan acostumbrados estamos en la cultura actual a referirnos al amor como motivación para casarse! Estimamos, sin embargo, que es un giro copernicano el que plantea el Concilio, especialmente cuando se tiene en consideración que ha habido otros énfasis, según lo hemos estudiado en la sinopsis histórica.

Muchos de los que vivimos la inserción eclesial desde la vida matrimonial hemos echado de menos este reconocimiento del amor conyugal -y no en un plano secundario- como fuente, también, de la dimensión procreadora y educativa. El Concilio ha asumido este reconocimiento definiendo el matrimonio en clave personalista: "La íntima comunidad conyugal de vida y amor está establecida sobre la alianza (foedus) de los cónyuges, es decir, sobre su consentimiento personal e irrevocable" (GS,48). Se ha desplazado, así, de un enfoque marcadamente jurídico donde campeaban expresiones como el "contrato matrimonial", el "débito conyugal", el ius in corpus a un enfoque de relación interpersonal, de encuentro afectivo (102). Lo contractual no se niega pero se articula desde otras prioridades. En efecto, el Código de Derecho Canónico de 1983 retoma el contenido de foedus -con las resonancias bíblicas que ello involucra- en el canon 1055,1 al definir el matrimonio (103), aspecto que no se encontraba en el Código de 1917.

Por su parte, la concepción integradora del amor conyugal que propone, se inscribe ya en la superación de la dicotomía entre amor espiritual y sexualidad genital: "Este amor, por ser eminentemente humano -ya que va de persona a persona con el afecto de la voluntad- abarca el bien de toda la persona, y, por tanto, es capaz de enriquecer con

(99) Cf. primera parte de este trabajo.

(100) Vidal, M., o.c. 414.

(101) Gaudium et Spes, nn. 47-52.

(102) Un clásico manual "De sexto" de los años preconciliares no negaba que el amor conyugal se hubiera excluido de la enseñanza de la Iglesia pero reconocía que "la teología pretérita atendía a él menos o apenas", Fuchs. J., De castitate et ordine sexuali, Roma, 1963, p. 42.

(103) "La alianza matrimonial, por la que el varón y la mujer constituyen entre sí un consorcio de toda la vida, ordenado por su misma índole natural al bien de los cónyuges y a la generación y educación de la prole, fue elevada por Cristo Jesús a la dignidad del sacramento entre bautizados" (Canon 1055,1). 
una dignidad especial las expresiones del cuerpo y del espíritu y de ennoblecerlas como elementos y señales específicas de la amistad conyugal" (GS, 49,1).

Estamos, aquí, ante otro desafío: asumir positivamente el amor, como realidad fundante del matrimonio pero depurarlo, a su vez, de equívocos reduccionistas. Es en la cultura contemporánea y con el desarrollo de las ciencias humanas donde la dimensión del amor se ha puesto de mayor relieve. En ello ha influido poderosamente la toma de conciencia de la subjetividad interior de la persona, la necesidad de destacar la relación interpersonal, la valoración que se ha dado a la comunicación como forma de encuentro. Sin embargo, la misma pluralidad semántica que la palabra amor encierra ha llevado al surgimiento de diversos equívocos. Estos no consisten en lo que se afirma del amor sino en lo que se deja de afirmar, es decir, en reducirlo a un solo aspecto desconociendo su riqueza de contenido. Detengámonos en dos equívocos que se manifiestan especialmente en la cultura popular cuando se habla del amor: por una parte, identificarlo con "hacer el amor" (104) y, por otra, reducirlo a una experiencia de enamoramiento (105). Un camino privilegiado para auscultar la cultura de un pueblo es ir al mundo de la canción y la poesía. En innumerables ocasiones se canta o poematiza el amor en el preponderante sentido de encuentro físico, epidérmico. Sin embargo, el solo deseo de intimar genitalmente no es todavía necesariamente una expresión de amor. Quiere decir, entonces, que este es algo más que el deseo de poseer o ser poseído. A su vez, en el enamoramiento se producen situaciones sensoriales emocionantes, "embriagadoras", que hacen de esta experiencia algo fascinante, asimilándose todo el amor a esta única dimensión. Si a lo anterior se une esa curiosa sensación de "levitación" que experimentan los enamorados (las personas se encuentran "succionadas" por la personalidad del otro) se comprende, entonces, por qué esta experiencia "arrase" -especialmente en el mundo juvenil- con el contenido de todo el amor. Una vez más, la canción y el poema vienen a corroborar esta reducción del amor a la exclusiva sensación de "sentirse enamorado". En la situación del enamoramiento hay "una entrega sin querer", porque se da en niveles sensoriales y emocionales donde no cuenta mucho la voluntad. En cambio, en el amor maduro hay un "querer entregarse", es decir, el amor es una decisión, un acto de la voluntad donde hay una raíz reflexiva y donde está presente la lealtad, la fidelidad, la responsabilidad. Por eso el amor conyugal se expresa en un consentimiento que es, ni más ni menos, la decisión libre y lúcida de donarse en

(104) "Como la mayoría de las personas unen el deseo sexual a la idea del amor, con facilidad incurren en el error de creer que se aman, cuando se desean físicamente. Es verdad que el amor puede inspirar el deseo de la unión sexual, pero en ese caso, la relación física se halla libre de avidez, del deseo de conquistar o de ser conquistado porque ese deseo está unido a la ternura. Pero si el deseo de unión física no está estimulado por el amor, es decir, si el amor erótico no es a la vez un amor fraterno, nunca conduce a la unión salvo en un sentido orgiástico y transitorio. La atracción sexual crea, por un momento, la ilusión de la unión, pero sin amor tal ‘unión' deja a los desconocidos tan separados como antes" (Fromm, E., El arte de amar, 1970, p.63) (El destacado es nuestro).

(105) "El amor de enamoramiento... se caracteriza por contener, a la vez, estos dos ingredientes: el sentirse ‘encantado' por otro ser que nos produce 'ilusión' íntegra y el sentirse absorbido por él hasta la raíz de nuestra persona, como si nos hubiera arrancado de nuestro propio fondo vital y viviésemos trasplantados a él, con nuestras raíces vitales en él” (Ortega y Gasset, J., Estudios sobre el amor, 1958, p. 37.) 
"salud y enfermedad, en riqueza y en pobreza" y de modo definitivo. Está claro que este tipo de amor no desconoce el valor de la atracción sensible y la fascinación del enamoramiento, pero va más allá de una exclusiva emocionalidad.

Para "decir verdad" en la enseñanza de la Iglesia en la materia es necesario superar, entonces, los reduccionismos biológicos y emocionales sin desconocer la importancia de la expresión corporal de la sexualidad ni la necesaria dimensión sentimental. De este modo es posible llegar a depurar el contenido del amor humano y entenderlo como una realidad compleja que implica 'ágape' y 'eros' a la vez; dar y recibir al mismo tiempo, donación y recepción mutuas. Cuando se da esta reciprocidad, el amor humano conlleva un vivir comunicándose, un comportarse dialógicamente. Lo opuesto, entonces, es vivir de modo egoísta, cortar toda relación de apertura y encuentro. Desde esta perspectiva, afirmamos que ante el amor 'agapeico' no hay sombra alguna de egoísmo. Pensar un 'ágape' egoísta es una verdadera contradictio in terminis. En cambio, al 'eros' le acecha un peligro (aunque no necesariamente caiga en él): el riesgo de autoengañarse y estimar que la persona se está donando cuando, en verdad, solo está buscando su propia y exclusiva satisfacción. Este peligro no hace incorrecta la dimensión erótica del amor pero la hace riesgosa. La manera de sortear esta dificultad es asumir un comportamiento tal que en el mismo momento en que la persona esta recibiendo (eros) tiene una actitud de entrega y donación (ágape). Se trata de "agapeizar el eros". De ahí que en la vida conyugal, sea necesario que las personas se amen, como señala Fromm, con amor erótico y, a la vez, con amor fraterno.

Volvamos a la enseñanza del Vaticano II. La intimidad sexual la presenta como una expresión específica del amor conyugal: "Este amor tiene su manera propia de expresarse y perfeccionarse. En consecuencia, los actos con los que los esposos se unen íntima y castamente entre sí, son honestos y dignos y, ejecutados de manera verdaderamente humana, significan y favorecen el don recíproco (106), con el que se enriquecen mutuamente en un clima de gozosa gratitud" (GS. 49,2). El texto, a nuestro juicio, es clave para entender que se ha superado la dicotomía que acompañó por tantos siglos la doctrina de la Iglesia al referirse al matrimonio. No estamos, aquí, ante una reiteración de la licitud del finis operantis. Derechamente se afirma que las expresiones específicas del amor conyugal son "honestas y dignas" y, al no tratarse de un elemento supperaditus, forman parte del mismo finis operis. Sin forzar los textos, estimamos que la manera más propia y peculiar con que los esposos pueden manifestarse su amor conyugal es la intimidad sexual que solo se legitima al interior de la vida matrimonial para vivir en castidad conyugal. Es obvio que no es la única manera de hacer patente este amor, pero sí su modo más específico. Todos los otros gestos de expresión corporal (un apretón de manos, un abrazo, un beso) se pueden dar entre diversas personas expresando amor, pero solo se llega a ser "una sola carne" con el gesto de la intimidad conyugal "realizado al modo humano" (107). Es, precisamente, el sentido que tiene la "consumación" del matrimonio y no solo su celebración.

(106) El destacado es nuestro.

(107) "El matrimonio válido entre bautizados se llama solo rato, si no ha sido consumado; rato y consumado, si los cónyuges han realizado de modo humano el acto conyugal apto de por sí para 
Otro texto conciliar, en la misma línea, nos abre incluso a un esbozo de fenomenología sexual diferencial: "La índole sexual del hombre y la facultad generativa humana superan ampliamente lo que de esto existe en los grados inferiores de la vida; por tanto, los mismos actos propios de la vida conyugal (108), ordenados según la genuina dignidad humana, deben ser respetados con gran reverencia" (GS. 51,3). Nos encontramos ante una exposición serena y positiva de la sexualidad vinculada con la posibilidad de ser un lenguaje de comunicación, aspecto que solo puede ocurrir en la especie humana. Lo afirmado está en sintonía con los hallazgos de la psicología contemporánea, para la cual el sexo no es algo extraño a la persona, sino que por el contrario, la sexualidad impregna toda la personalidad y sus manifestaciones en la existencia, dándoles su carácter varonil o femenino. Es una comprensión que supera, entonces, la pura expresión genital para llegar a ser gestos significantes del encuentro de dos interioridades en el amor (109). "Estamos lejos, no solo del pesimismo, sino también del hedonismo, que es calificado como una profanación del auténtico amor conyugal” (cf. nn. 47 y 49 de GS) (110).

Lo recién comentado nos sitúa ante un nuevo desafío: evitar el constante peligro de dicotomía y ofrecer una antropología unitaria donde el ser humano se entienda 'corpore et anima unus' (111). Esta unidad nos abre, además a otro desafio: la comprensión del placer, como parte de la experiencia humana, especialmente (aunque no exclusivamente) en el campo del comportamiento sexual. Nos referimos, aquí, a uno de los "caballos de batalla" con que se critica la enseñanza de la Iglesia en el campo de la sexualidad. Es casi innecesario decir que la cultura contemporánea es fuertemente hedonista y el discurso moral eclesial suele quedar desfasado o incomprendido cuando entra con un a priori de reproba-

engendrar la prole, al que el matrimonio se ordena por su misma naturaleza y mediante el cual los cónyuges se hacen una sola carne" (Canon 1061.1). Para comprender, a cabalidad, lo que hemos destacado al transcribir el canon ("de modo humano") conviene tener presente lo que se expresa en un comentario destacado: "Se trata de asegurar el mínimo de racionalidad, voluntariedad y normalidad que permita calificar el acto humano en su contenido y en su realización: humano por tener conciencia de lo que se hace y advertencia acerca del propio acto; humano por no lesionar la libertad de la persona del otro cónyuge; y humano por respetar el orden natural del acto mismo, sin contradicción objetiva con él. Se excluye, por consiguiente, la actuación irracional, violenta, gravemente desproporcionada o antinatural", Bañares, J.I., Comentario exegético al Derecho Canónico, Vol.III/2 Instituto Martín de Azpilcueta, Facultad de Derecho Canónico, Universidad de Navarra, Pamplona, 2002, p.1097. Dejamos solo mencionado, a la luz del canon y del comentario, el sentido que puedan tener los gestos y comportamientos de intimidad conyugal, realizados en virtud de un auténtico amor matrimonial que no son "apto(s) de por sí para engendrar la prole". Nos referimos, en concreto, a la amplia variedad de conductas conyugales de la cual nos informa la sexología contemporánea, que pueden constituir manifestaciones de auténtica comunicación mutua, sin ser impuestas ni forzadas unilateralmente pero que no se encaminan, por su naturaleza, a engendrar la prole. ¿Cabrían dentro del rango de expresiones "honestas y dignas" de amor conyugal? La pregunta en sí constituye otro desafío, ahora desde la sexología, al discurso que plantea la moral cristiana en un campo hoy día cada vez más frecuente en el comportamiento matrimonial.

(108) El destacado es nuestro.

(109) Cf. la distinción entre genitalidad y sexualidad que propusimos en la parte primera de esta ponencia.

(110) AA.VV, Sexualidad... o.c. 264.

(111) Gaudium et Spes, 14. Interesa releer, en este punto, el aporte de Veritatis Splendor al comentar el lugar que tiene el cuerpo humano en las cuestiones de la ley natural: VS., 48-50. 
ción a esa cultura (112). Por otra parte, la amplia sospecha, a lo largo de los siglos, acerca de la bondad ética del placer (113) "cobra su revancha" en esta hipervaloración del placer en el mundo actual y en la incapacidad de postergar satisfacción para consumir de inmediato (114). Ahora bien, "como la historia lo demuestra... la mayoría de las morales no han sabido impedir esta absolutización del placer sin caer en otro equívoco situado en el extremo opuesto. Como ha puesto de relieve el psicoanálisis freudiano, se diría que no podemos impedir la absolutización del placer sino a base de anularlo y destruirlo. Se pretende así desmitificar el placer a base de una mitificación, en que se niega la existencia del placer como placer. Una cosa, en efecto, es que reconozcamos que el placer no lo es todo (absolutización) y otra que digamos que no es nada (anulación). Además, en este proceso de represión y anulación del placer, en el fondo, se sigue pensando que es un absoluto. Se le prohíbe al placer ser lo que es, es decir, la perfección y totalización de algo, con el pretexto de que algunos puedan considerarlo como un todo. Esto equivale a decir que se le sigue considerando como lo que no es en realidad" (115).

Como reacción a una visión puritana, se ha llegado al extremo opuesto: hacer de la búsqueda del placer sexual un absoluto, un verdadero ídolo, sacrificando la comunicación interpersonal y la apertura a la vida a este dios. Estas visiones antagónicas demuestran que el placer es una realidad ambigua. En efecto, el deseo de felicidad que se anida en el corazón humano no tiene límites, toda persona aspira a ser feliz, es apeiron y la mayoría de los humanos viven para satisfacer ese deseo. Ahora bien, la persona espontáneamente, cuando quiere ver colmada su aspiración de felicidad, piensa en el placer. Y ello es lógico porque este es teleios, es decir, termina y concluye una acción. El placer, como lo expresa Aristóteles, es la perfección de las cosas (116). Algo semejante plantea S. Tomás de Aquino al hablar de la delectatio: "Y por eso, cuando algo se constituye en su propia operación connatural y no es impedida en ella, le sigue un placer que acaba perfecta-

(112) "El juicio acerca de lo que es bueno y malo -y la consiguiente conducta moral- dependen en gran medida de lo que en una cultura se considera bueno o malo, y de las consiguientes normas de conducta. Esto es así -sea bueno o malo, guste o no- debido a que cada uno llega a ser persona, madura como ser humano, gracias a los procesos de socialización..., mediante los cuales el individuo va asumiendo -al comienzo sin ninguna posibilidad de selección crítica- la cultura de los diversos grupos a los que pertenece. Por esto, no suele tener resultado real la mera proclamación de la doctrina moral católica. Para que lo tuviera debería ir acompañada y permeada por una toma de conciencia de esta imbricación con lo cultural y dirigir ahí el llamado a la conversión". Silva, S., Sobre moral y cultura (Notas internas de aporte a la Comisión Doctrinal del Episcopado), 2000, p.1. La Iglesia ha elaborado hermosamente una teología del dolor y ello es perfectamente entendible: Jesucristo, varón de dolores, ha hecho "comprensible" el dolor si es redentor. De lo contrario es un absurdo. Está en deuda, sin embargo, con la elaboración de una teología del placer, para redimir, también, esta realidad puesta por Dios en la vida humana

(113) Cuenta la historia que en círculos jansenistas se bordaba en las ropas íntimas de los novios la máxima de "Pas plaisir mais devoir" (Cf. Hortelano, o.c. 549).

(114) El "goza ahora, paga después" es uno de los lemas de nuestra cultura. En la misma línea se imponen ciertos spots publicitarios: "obedece a tu sed" o la letra de algunas canciones populares: "Dale alegría a tu cuerpo, Macarena".

(115) Horlelano, A., o.c., ibíd.

(116) Cf. Aristóteles, Política II, 7, 1.267, b 3-5. 
mente su ser" (117). Por tanto, el deleite ha sido puesto por Dios en la naturaleza humana como una atracción para llevar adelante tareas importantes. Mientras más relevantes sean esos cometidos, más fuerte será el placer que se consigue al realizar los comportamientos que tienen a esas tareas por fin (cf. Summa I-II, 31, 3). Es posible que Santo Tomás esté pensando exclusivamente en la tarea procreativa. Según lo que hemos manifestado en párrafos anteriores, la expresión de amor también se convierte en un cometido central e importante. "La misma integración del placer en el amor mutuo, nos hace percibir la necesidad de la castidad, como presencia necesaria del amor en la sexualidad y genitalidad, para una armonía conyugal, para el favorecimiento de la intimidad, unidad y solidez del matrimonio mismo" (118) y para la apertura a una paternidad responsable.

En lo expuesto en líneas anteriores radica, precisamente, la ambigüedad del placer: si corona y culmina un acto particular aislado no es capaz de satisfacer la permanente aspiración a la felicidad que busca el ser humano. Este deseo, como se dijo, no tiene límites, es algo insaciable, nunca se da por satisfecho (119). Si el deleite dura un instante no está en condiciones de extenderse en una duración prolongada siempre. El equívoco, en la materia, es identificar, entonces, placer con felicidad pretendiendo que aquel pueda satisfacer plenamente nuestra capacidad de ser felices. De ahí que absolutizarlo sea un camino equivocado para colmar aquella aspiración. Queda necesariamente corto. Teniendo en cuenta, entonces, el equilibrio para no idolatrarlo ni denigrarlo, cabe preguntarse, ¿qué sentido tiene el placer sexual? Contra lo que pretenden algunas corrientes de pensamiento contemporáneo que lo explican como la satisfacción de los impulsos instintivos del ser humano, planteamos que su sentido se encuentra en su apertura a la corporeidad. En efecto, gracias al placer sexual la persona se siente identificada con su propio cuerpo. Para corroborar lo expresado basta una observación que la aportan experiencias de intenso sufrimiento físico. Llama la atención que ante situaciones de enorme dolor corporal (piénsese, por ejemplo, en casos de tortura) la persona tiende a mirar su propio cuerpo como un ente extraño, hasta hostil. Por el contrario, ante la expresión placentera de la sexualidad, la persona se goza en su corporalidad y se reconcilia con su propio cuerpo. Este le revela su propia densidad. Pero hay más. El placer sexual no se queda en el descubrimiento centrado en la propia corporalidad sino que se abre a la persona hacia la proximidad corporal del otro (120). Cuando se trabaja con otra persona, no hay comunicación directa sino que mediada por la obra que se hace en común. En cambio, en las relaciones sexuales se establece un encuentro inmediato, de tú a tú, de piel a piel, gracias a la comunicación corporal que suprime las barre-

(117) Summa Theologica I-II, 31,1 ad.1. Incluso S. Tomás entiende el placer sensible como un remedio contra la tristeza y el dolor humanos en vista a renovar las energías y dar reposo (cf. Summa I-II, 38,1 ) y llega a ser un eco de la beatitud divina: "Ahora bien, hay que tener presente que toda delectación es un cierto accidente propio que se desprende de la bienaventuranza o de alguna parte de ella" (Summa I-II, 2, 6)

(118) AA.VV. Sexualidad... o.c. 267.

(119) Es la aguda intuición agustiniana de "Fecisti nos ad Te, Domine, et inquietum est cor nostrum, donec requiescat in Te" Confess. 1,1; PL 32, 661.

(120) Gaudium et Spes habla de "(los esposos) se enriquecen mutuamente en un clima de gozosa gratitud" $(49,2)$. 
ras. Es la concreción de lo que somos antropológicamente, es decir, una unidad psicosomática.

Sin embargo, y ya lo dijimos en párrafos anteriores, no hay que idolatrar el placer sexual sino vivirlo simplemente como lo que es: una modesta introducción al encuentro con la otra persona. Quedarnos en el exclusivo placer, como si fuera todo, y no abrirlo a dimensiones más profundas de comunicación integral con otra persona, sería pretender del deleite sexual algo que no puede dar, lo que no quita que tenga valor en sí mismo. Siguiendo la propuesta antropológica de unidad, es necesario no quedarse en el cuerpo de la otra persona sino llegar hasta lo más hondo de ella, hasta "tocar" su ser profundo donde es único. De lo contrario, se toma contacto con un cuerpo anónimo, con una epidermis cualquiera. Sin embargo, el camino que llega hasta la singularidad irrepetible de la persona pasa necesariamente a través de su cuerpo. Desconocer esta realidad es quitar a esa persona su peso específico.

Vayamos, una vez más, a Gaudium et Spes para entrar en nuevos desafíos. La enseñanza del Concilio manifiesta que amor y procreación no pueden ir separados. Por ello, el Concilio expresa que el amor conyugal, por su propia naturaleza, está ordena$d o$ (no subordinado) a la procreación (GS, 50,1) y ello es perfectamente comprensible. En efecto, hay una lógica interna entre el amor que "camina" hacia la vida (como el odio "camina" hacia la muerte). Desde el amor se afirman tres vidas: la de uno mismo, la del ser amado y las nuevas vidas que son la culminación del amor matrimonial. La sinopsis histórica nos hizo ver la casi exclusiva justificación del matrimonio en función de la procreación; el desafio, ahora, es evitar el énfasis opuesto: sobrevalorar tanto la dimensión afectiva que se llegue a un egoísmo de dos. Hay que reconocer que la época actual corre el peligro de instalarse en una cultura anti-life. Es necesario decir que un matrimonio que pudiendo dar la vida no la da, vive un amor que está a medio camino y que no ha llegado a plenitud. El Concilio, sin embargo, no privilegia un sentido sobre otro, de donde no retoma la terminología clásica de fin primario y fin secundario (121). Es claro que ello no puede significar una inversión de sentidos sino una vinculación. Ahora bien, la manera como establecer el nexo entre las manifestaciones del amor conyugal y una responsable transmisión de la vida fue objeto, como sabemos, de intensos y profundos debates en el aula conciliar, hasta el punto que la resolución precisa quedó abierta. La respuesta la vino a dar la Encíclica Humanae Vitae de Pablo VI, después de recibir el informe de la Comisión pro Estudio de Población, Familia y Natalidad, informe que no llegó a acuerdo unitario, presentándose, así, una posición de mayoría y otra de minoría. La Encíclica se inclinó por esta última, consagrando la corrección ética del recurso a los ritmos naturales y la ilicitud del anticoncepcionismo artificial. En cuanto a su línea argumentativa afirmó la "inseparable conexión, que Dios ha querido y que el hombre no puede romper por propia

(121) Con todo, hay ciertas corrientes teológicas o canónicas que, a pesar del silencio conciliar, siguen insistiendo que la terminología empleada antes del Concilio mantiene su validez. Estimamos, con buenas razones, que tales planteamientos son inadecuados. La misma manera de hablar de documentos magisteriales ulteriores se refiere a 'significados vinculados', más que a finalidades prioritarias o secundarias. 
iniciativa (122), entre los dos significados del acto conyugal: el significado unitivo y el significado procreador" (123).

Posiblemente la intención de Pablo VI al promulgar la Encíclica fue concluir con la materia pendiente que dejó el Concilio (sobre los medios para regular la natalidad). Sin embargo, el documento fue el detonante para abrir muchos de los temas contemporáneos que hoy se debaten en la teología moral: la distinción entre el bien o valor premoral u óntico (124), por una parte, y el bien o valor moral, por otra; la comprensión de una ley natural con énfasis más biológico (línea de Ulpiano) o más racionalista (línea de Cicerón), advirtiendo que en S. Tomás hay textos en ambos sentidos; la opción por el deber mayor ante situaciones de auténtico conflicto de deberes; la respuesta moral considerando una ética de opción fundamental y no primordialmente una moral del acto; la elaboración de la moral desde la persona y no solo ex obiecto; la valoración y discernimiento de los comportamiento morales asumiendo un enfoque deontológico o un enfoque teleológico, etc. Muchos de estos temas controversiales fueron abordados en la Encíclica Veritatis Splendor (1993), precisándose, así, el pensamiento del Magisterio.

Humanae Vitae dio origen, además, a desafíos pastorales que se han mantenido en el tiempo y que podrían formularse, especialmente, como el desfase entre la moral formulada por la encíclica y la moral vivida por una parte significativa de cristianos que conocen los planteamientos pontificios pero no guían su comportamiento en materia de regulación de la natalidad por las directrices del documento (125). Como puede comprenderse, el simple enunciado temático abierto por la Encíclica y algunas de las situaciones pastorales generadas da origen a una cantidad grande de problemas relacionados con temas de sexualidad, algunos de los cuales pugnan, en su resolución, con planteamientos del magisterio. Digamos algo sobre esos desafíos que se recogen desde la cultura actual, sin tener la pretensión de ofrecer caminos de orientación decantados o precisos:

- el siempre presente conflicto de la comprensión del contenido de la ley natural. Llama la atención que el Vaticano II emplea solo una vez la expresión

(122) El destacado es nuestro.

(123) Humanae Vitae (H.V.), 12.

(124) Este valor se refiere al bien anterior a la responsabilidad de lo humano. Expresándolo en un ejemplo pertinente al tema sería el caso de la integridad fisiológica de la mujer, de tal modo que la ligadura de trompas sería un mal óntico. Llegaría a convertirse en bien moral cuando lo asume la libertad y responsabilidad de la persona y ese procedimiento quirúrgico se realiza en la perspectiva de humanización de la mujer, no de mutilación. De este modo, aquel mal óntico (ligadura de trompas) podría llegar a ser un bien moral, según la razón que se tiene al asumirlo.

(125) Este distanciamiento se ha expresado en conductas diferentes entre fieles que quieren vivir activamente su compromiso cristiano, aunque no sigan las orientaciones de Humanae Vitae: algunos participan plenamente de la vida sacramental sin pensar, en conciencia, que pudieran estar apartes de la recepción de la Eucaristía; otros piden consejo a los sacerdotes, con frecuencia dentro del Sacramento de la Reconciliación. Ahí se producen, a su vez, orientaciones diversas. Algunos pastores niegan la absolución a aquellos cristianos que no estarían dispuestos a seguir las orientaciones de Humanae Vitae; otros aconsejan a los penitentes que procuren, en lo posible, acercarse a las directrices de la Encíclica pero les otorgan la absolución. El resultado suele ser un gran desconcierto y lo que es más grave, el apartarse por mucho tiempo, para aquellos que no han recibido la absolución, de la vida cristiana y sacramental o "la recomendación" entre los mismos fieles de ir donde sacerdotes que no les pondrán problemas en esta materia. 
misma, la cual es retomada con fuerza en los planteamientos de Humanae Vitae en orden a fundamentar la licitud de los métodos naturales y la proscripción de los artificiales. Queda claro, sin embargo, que nuestra cultura tiende a identificar lo natural con lo artificial (126) y a los hombres y mujeres que viven inmersos en esa cultura se les hace difícil renunciar a lo que les puede proporcionar la ciencia y la técnica si ven en ello una opción humanizadora para transmitir responsablemente la vida y no un camino hacia el egoísmo o hedonismo (127). Una vez más queda abierta la interrogante que en palabras del Concilio podría formularse así: “...los teólogos, guardando los métodos y las exigencias propias de la ciencia sagrada, están invitados a buscar siempre un modo más apropiado de comunicar la doctrina a los hombres de su época; porque una cosa es el depósito mismo de la fe, o sea, sus verdades, y otra cosa el modo de formularlas, conservando el mismo sentido y el mismo significado" (GS. 62,2). La dificultad o, derechamente, la incapacidad en muchos cristianos para entrar en la comprensión de lo natural propuesto por la Encíclica nos pone ante diversas interrogantes: ¿rebeldía a la iluminación?, ¿problemas de lenguaje en la comunicación del mensaje?, ¿mediaciones culturales no asumidas por el agente iluminador que dificultan la credibilidad de la enseñanza? ¿puntos de partidas diversos en la cultura actual para entender "lo natural"?

- La conexión entre el significado unitivo y el procreativo de la intimidad conyugal. Humanae Vitae habla de inseparable conexión que la persona no puede separar por propia iniciativa. Es el fundamento para proscribir la anticoncepción artificial y también la fertilización in vitro simple (Cf. Donum Vitae, II, B. 4c.). Estudiado este postulado desde un enfoque biológico, cabría precisar lo siguiente: evitar toda forma de fisicismo en la comprensión de esta conexión: "Notemos que en el plano de los hechos no se da (una...) sincronización entre la unión sexual y la procreación. En efecto, dado que la fecundación acontece en el tercio superior de las trompas, la procreación acon-

(126) Hace más de treinta años Ch. Curran, destacado moralista de los EE.UU. expresaba en un artículo sobre la Moral de los Trasplantes lo siguiente: "Creo que a los teólogos católicos les cuesta encarar estos temas porque aún continúan pensando en términos del hombre precientífico. Los filósofos estoicos de la antigua Grecia plantearon el interrogante: ¿en qué forma el hombre hallará la felicidad? Su respuesta era muy simple: está de acuerdo con la naturaleza. Si hace frío, no salgas. Cuando haga calor, sácate la chaqueta. Cuando sea de noche, acuéstate. Si hay una montaña en tu camino, rodéala. Todo esto tenía mucho sentido en los tiempos precientíficos. Pero el genio del hombre científico moderno, es que la naturaleza esté de acuerdo con él. Humaniza e interfiere a la naturaleza. Si hace calor afuera, pone en marcha el aire acondicionado. Si una montaña se atraviesa en su camino, la perfora con dinamita y construye un túnel. Dios le dijo al hombre que dominara la tierra, que usara de sus habilidades y de su tecnología para hacer la vida humana más humana. Pero recién estamos comenzando a comprender qué significa esto en el orden moral", Curran, Charles, debate con el Dr. Robert White sobre "Moral de los trasplantes", aparecido en la Revista "Sign" y reproducido en Revista "Ercilla" (Santiago, Chile), semana del 17 al 23 de julio de 1968.

(127) Juan Pablo II en Familiaris Consortio abordará el asunto desde una perspectiva antropológica, sin entrar en formulación de ley natural. En efecto, distinguirá dos maneras de aproximarse al tema de los medios para regular la natalidad: la antropología del árbitro que manipula y altera, sin darse donación total (recurso al anticoncepcionismo artificial) y la del ministro que se sirve y no manipula, dándose una donación total (recurso a períodos de infecundidad). Cf. Familiaris Consortio, 32, párrs. 4 y 5. 
tece, como mínimo, varias horas -e incluso días- después que los espermatozoides son depositados en el fondo de la vagina. Se da, por tanto, al nivel de los hechos, una inevitable disociación cronológica entre el significado unitivo y el procreativo del acto sexual" (128).

Por otra parte, para una adecuada comprensión del postulado, se plantea esta interrogante: ¿la conexión entre el significado unitivo y procreador es propia de la actividad humana, en la vida conyugal, por lo que tiene de 'acto sexual' o por lo que tiene de 'amor sexual', que se expresa en cada uno de los gestos sexuales y también en el conjunto de la vida conyugal? La pregunta nos sitúa antes dos visiones diferentes: una, que considera que la fecundidad está ligada a las leyes biológicas y ritmos naturales de la sexualidad, como reveladores de la voluntad de Dios; y otra, que "la fecundidad toma cuerpo en una actitud interior de toda la personalidad de los esposos y se actualiza en un proyecto global de fecundidad" (129). Estas dos visiones tienen su historia antes del Vaticano II y después de él, llegando el debate hasta épocas cercanas (130). Podríamos decir que ellas resumen el punto de partida deontológico y el teleológico para elaborar teología moral. Es claro que diversos documentos del magisterio contemporáneo se inclinan preferentemente por el primer enfoque (131). A su vez, el 'suelo cultural' donde se mueven creyentes y no creyentes 'de a pie' van, de preferencia, por el segundo énfasis. Se produce, entonces, un desfase entre el esfuerzo iluminador que quiere ofrecer la Iglesia y el sujeto al cual se dirige la enseñanza por incapacidad del eventual "iluminado" para asumirla o comprenderla. En efecto, el comportamiento sexual es susceptible de ser analizado desde el objeto (lo que se hace) o desde la persona (quien lo hace). Son puntos de partida que pueden llegar a consecuencias diferentes a la hora de valorar éticamente la conducta humana.

El 'humus' actual donde se mueve la comprensión del obrar sexual en la persona humana es más desde una perspectiva integral: "El proyecto de fecundidad es parte de la alianza matrimonial y del amor conyugal tanto como aquellos actos en los que se desea explícitamente una nueva concepción. Cuando no puede buscarse un nuevo embarazo, el acto participa, en alguna medida, de la misma plenitud y

(128) Gafo, J., ¿Hacia un mundo feliz?, Madrid, 1987, p. 73.

(129) Gatti, G., Morale matrimoniale e familiare, en "Corso di morale. III Koinonia (etica della vita sociale)", Brescia, 1984, 263.

(130) En el Congreso Internacional de Bioética organizado por la Academia Alfonsiana en 1988 "los asistentes pudieron ver dos metodologías de reflexión teológico-moral y dos modelos de moral. Häring propone una moral basada en la comprensión integral de la persona mientras que Caffarra hace radicar la moralidad sobre una ontología en apariencia de signo tomista, pero en realidad de confusa mezcla fenomenológica. El primer planteamiento propicia una moral exigente pero misericordiosa; el segundo afirma una moral de la intransigencia revestida de radicalismo ético", Schurr-Vidal, B. Häring y su nueva teología moral católica, Madrid, 1989, 77.

(131) Ello queda claro, por ejemplo, en la comprensión de la paternidad responsable que asume Humanae Vitae al incorporar el respeto a los procesos biológicos de la persona como parte de dicha concepción (cf. H.V.10), elemento que no se encuentra en Gaudium et Spes cuando trata el mismo punto (cf. GS, 50,2); en Veritatis Splendor al referirse al lugar que tiene el cuerpo en las cuestiones de la ley natural (Cf. VS, 48-50), con el agregado de la crítica y condena que hace el documento a las posturas teleológicas (consecuencialistas o proporcionalistas) en el campo de la moral (cf. VS, 74-75). 
dignidad. La vida conyugal debe ser considerada como un todo. Cualquier separación arbitraria de las dos funciones afecta también a la meta unitiva en sentido negativo" (132). Desde una enseñanza de moral objetiva ese 'humus' es distinto y se dirá que cualquier acto matrimonial debe quedar abierto a la transmisión de la vida, de donde no se podrá, entonces, establecer intencionalmente una separación entre lo unitivo y procreativo.

Si se trata de hacer que la enseñanza de la moral sexual se efectúe en términos de la comprensión de la gente es necesario llevar adelante, sin embargo, un proceso de "negociación de significados" (133). Ahora bien, ello implica hacer un esfuerzo por clarificar los sentidos que cada parte aporta, ponerse en el lugar del otro para desentrañar la parte de verdad que tiene su planteamiento, tomar en serio el diálogo (134) interdisciplinar, discernir qué es lo que se puede "negociar", etc. No nos cabe duda que en la vida de la Iglesia y señaladamente en la relación magisterio-comunidad creyente, esta "negociación de significados" es una tarea muy difícil de hacer (135) pero es una labor urgente a la hora de hacer creíbles las enseñanzas de la Iglesia en la materia en estudio y en otras. Es posible que una pista de acercamiento sea tender puentes entre un enfoque deontológico y otro teleológico, de modo que no sean visiones divergentes sino convergentes. ¿Lo teleológico no se anticipa o preanuncia, en parte, en lo deontológico? Responder en sentido positivo es valorar ambas dimensiones pero sin pretender absolutizarlas, descalificando la otra óptica. Conlleva asumir una dosis de flexibilidad que permita construir la verdad sobre la sexualidad acorde con la norma fundante de la moral cristiana que es el Evangelio pero entendida en apertura a los signos de los tiempos. Lo recién expresado se vincula con otro desafío que vamos a presentar.

- ¿Todo es pecado grave en el sexto mandamiento? Llama la atención que la tradición teológica de algunos siglos a esta parte haya enseñado que en el campo de la sexualidad no se dé parvedad de materia, es decir, que en el ámbito de las faltas sexuales todo sea objetivamente grave. Eso no ocurre en otras esferas de la teología moral, donde se enseña que se da, desde el punto de vista objetivo, una gradación de faltas, pudiendo hablarse de levísimo, leve, grave, muy grave. Es el caso, por ejemplo, en temas de moral social. "La discriminación efectuada entre el sexo y los restantes problemas éticos es demasiado evidente para que no surjan sospechas sobre su falta de objetividad. A

(132) Häring, B., Libertad y fidelidad en Cristo, II, Barcelona, 1981, p. 535.

(133) Expresión tomada de la ponencia-marco del presente Seminario: Verdugo, F., Consideraciones preliminares... o.c. p. 193. (cf. nota 2)

(134) “... el verdadero diálogo (día, a través de, no junto a) consiste... en una búsqueda conjunta e integrada de la realidad, mediante un intercambio de 'ojos' que nos permita realmente ver el mundo y la existencia no como yo o tú o como yo y tú, sino como nosotros”. Hortelano, A. o.c. 334.

(135) La sola interrogante de si los dialogantes están en el mismo plano es decisiva en un proceso negociador. ¿Se puede aplicar unívocamente la tarea de negociar significados en una Iglesia constituida jerárquicamente? ¿Dice algo la distinción entre Iglesia “misterio” e Iglesia “institución sociológica"? También es crucial la consideración de cómo opera el ejercicio del poder en ese proceso. 
lo mejor, si hubiéramos tomado en serio las afirmaciones tan repetidas de Cristo sobre el peligro de las riquezas y la experiencia histórica de tantas injusticias elaboradas con el dinero, nuestra moral económica sería mucho más rigorista que la ética sexual. El Evangelio, al menos, se muestra mucho más comprensivo con las deficiencias sexuales, aunque también las condena, que con otros pecados en los que hemos admitido una benevolencia mayor por no enjuiciarlos siempre como graves" (136) La mentalidad contemporánea tiene dificultad para comprender esta diferencia, lo que no ha ocurrido, ciertamente, en otras épocas de la historia. Es necesario, entonces, reflexionar más en profundidad sobre el desafío que plantea la enseñanza doctrinal de la Iglesia en este punto preciso.

Según estudios especializados (137) tal enseñanza no habría concitado la unanimidad de los moralistas, pudiendo otorgarse una valoración teológica de "opinión común" (138). Más bien, la enseñanza surge en un contexto de medida prudencial ante un eventual pronunciamiento de la Santa Sede que podría haber llegado a establecer tal doctrina ante la avalancha de opiniones demasiado laxas en la materia. Es lo que afirman diversos textos de teología moral estudiados (139). Lo cierto es que esta medida prudencial -teniendo en consideración lo expresado en la notahizo cristalizar una enseñanza que pasó a las Institutiones Theologiae Moralis (140) llegando, así, hasta el Vaticano II. Lo manifestado hasta aquí no pretende, ciertamente, negar la importancia y la gravedad que puedan tener las faltas en este terreno. Desde el momento que la sexualidad "toca" la integralidad de la persona en su

(136) López Azpitarte, E., o.c. 172

(137) Cf., por ejemplo, J.M. Díaz Moreno, La doctrina moral sobre la parvedad de materia 'in re venerea' desde Cayetano hasta Alfonso. Estudio antológico y ensayo de síntesis, en Archivo Teológico Granadino 23 (1960) 5-138. El mismo autor en estudio ulterior: La gravedad moral en la lujuria. Notas de teología pastoral en torno a la parvedad de materia, Sal Terrae 62 (1974) 609. Bajeén, M., Nuevos datos acerca de la parvedad de materia 'in re venerea'”, Pentecostés XIII (1975) 93-103. López Azpitarte menciona el "documentado estudio de K.H. Kleber, De parvitate materiae in sexto. Ein Beitrag zur Geschichte der katholischen Moraltheologie, Pustet, Regensburg, 1971" (al cual no hemos accedido), en o.c.171. Allí manifiesta que Kleber "analiza los documentos de la tradición para demostrar cómo no se ha dado un pleno consentimiento en este punto", o.c. ibíd, nota 38.

(138) o.c. 170

(139) La medida prudencial tendría su origen en un decreto de Claudio Acquaviva, general de los jesuitas, fechado el 24 de abril de 1612, y en el contexto señalado, donde prohibía a los profesores de la Compañía "defender pública o privadamente a partir de esa fecha la parvedad de materia en cuestiones sexuales, no solo como doctrina probable, pero ni siquiera como tolerable y lo prohíbe en virtud de santa obediencia y bajo pena de excomunión y de privación de la enseñanza, de voz activa y pasiva y de cualquier cargo, aparte de otras penas que podían imponerse a los transgresores", Hortelano, A., o.c. 542. Llama la atención, ciertamente, lo tajante del decreto y su motivación profunda no es fácil de dilucidar. Surge, así, una enseñanza aceptada, al parecer, en virtud de la obediencia y que luego se procura justificar doctrinalmente. Con todo, hay constancia histórica que, después del Decreto de Acquaviva, hubo algunos moralistas jesuitas destacados que siguieron afirmando la parvedad de materia in re venerea. Tal es el caso de Tomás Sánchez, talvez el más conocido moralista de las "instituciones" postridentinas y primer tratadista sistemático del sacramentos del matrimonio (Cf. Bajeén, M., Pensamiento de Tomás Sánchez sobre moral sexual, Granada, 1976).

(140) Los primeros manuales de teología moral que surgieron a partir del Concilio de Trento, para ser usados en los Seminarios, creación -también- de ese Concilio. 
maduración y en su relación con los demás, un desorden moral en este campo puede catalogarse de grave. Es verdad, también, que la enseñanza ha distinguido entre la objetividad del acto y la subjetividad de la conciencia (141) y por ese camino se han enfrentado muchos conflictos hasta el punto que, en ocasiones, el consejo pastoral ha sido dejar en "conciencia invenciblemente errónea" (142). La dificultad de comprensión está en que la menor transgresión constituya siempre y objetivamente pecado grave. "La malicia del acto radica en la renuncia a vivir los valores de la sexualidad, que en cada gesto concreto se eliminan. Si una conducta aislada no llegara a herir gravemente el sentido de aquella, se debería admitir, como en otros campos de la moral, la parvedad de materia" (143). A lo expresado es necesario preguntarse si una falta sexual ¿rompe o no la opción fundamental de una persona, es decir, su orientación definitiva hacia Dios? (144) La respuesta no puede ser un sí o un no tajante y preciso. Para contestar, será necesario tener en cuenta no solo la naturaleza de esa falta, sino los valores que quedan comprometidos y la vida moral de la persona en su conjunto (145). Desde otra perspectiva, también sería necesario precisar que cuando se habla de un comportamiento intrínsecamente malo (146) no significa, por ese solo hecho, que estamos ante una falta mortal, confusión que suele introducirse en los planteamientos morales. "Una acción se considera intrínsecamente pecaminosa cuando a) se valora como mala por su misma naturaleza y no por estar mandada, y b) o hay que admitirla como tal en todas las circunstancias y ocasiones, sin ninguna posibilidad de justificación" (147).

Lo que hemos presentado en los párrafos recientes tiene alta importancia para la manera de "decir verdad" sobre el comportamiento sexual. En efecto, por muchos

(141) Innumerables documentos del magisterio así lo señalan. Por ejemplo, al referirse a la masturbación o al comportamiento homosexual se establece su malicia objetiva grave pero se admite, también, la posible disminución de ella en virtud de una conciencia no suficientemente libre o consciente de lo que hace (Cf. La declaración acerca de ciertas cuestiones de ética sexual, Ciudad del Vaticano, 1975, nn. 8 y 9). En la misma línea de la distinción entre objetividad del acto y posible subjetividad de la conciencia, el Catecismo de la Iglesia Católica al tratar el sexto mandamiento (nn. 2331-2400).

(142) Es claro que esta distinción no se aplica solo a materias sexuales sino que se refiere a toda situación de comportamiento moral. La manera de articular ambas dimensiones -la objetiva de la ley moral con la subjetiva de la conciencia- puede verse en Romo, W., La conciencia moral... o.c. Teología y Vida XLII (2001) 172-201.

(143) López Azpitarte, o.c.173.

(144) Tenemos conciencia que Veritatis Splendor critica aquellas corrientes teológicas que proponen una opción fundamental "atemática", es decir, una elección vacía de contenido y que no se expresa, por tanto, en actitudes y actos concretos (cf. VS. 65-68). No es el caso de lo que aquí estamos planteando.

(145) En teología moral contemporánea suele hacerse una distinción entre un pecado grave y un pecado mortal. Los criterios para catalogar una falta en un campo o en otro son diferentes. La gravedad mira "la cuantía" de daño que esa falta involucra (y ello admite gradaciones mayores o menores). La mortalidad mira a la ruptura de la opción fundamental por Dios del que comete esa falta. Con mucha frecuencia una falta grave será mortal y una leve será venial. Sin embargo, no es posible afirmar que siempre y en todos los casos una falta grave, por el solo hecho de serlo, sea automáticamente un pecado mortal. A su vez, también podría ocurrir que una falta leve llegue a ser mortal en la conciencia de una persona.

(146) Cf. Concha, P., El 'intrinsece malum' en la discusión teológico-moral del posconcilio. La Veritatis Splendor y la ética de la autonomía teónoma, Granada, 2002 (Tesis doctoral del mencionado autor, presentada ante la Facultad de Teología de Granada).

(147) López Azpitarte, o.c. 377, nota 32. 
siglos se ha vivido una suerte de obsesión con respecto a los pecados sexuales (148) y el sexto mandamiento se ha convertido, así, en el centro de la conducta moral. "Cuántos hombres, al confesarse, después de casados, decían no tener ningún pecado, precisamente porque ya estaban casados. La pesadilla del sexto ha condicionado enormemente la teología moral, la predicación y especialmente la confesión" (149). Las causas de este fenómeno son muchas y complejas: el dualismo espiritualista que hemos analizado en la parte histórica y que, en realidad, es pre o extracristiano; la época en que cristaliza la conciencia moral que coincide con la crisis de la adolescencia donde las primeras reglas o poluciones nocturnas orientan esa conciencia al campo de lo sexual; el hecho que la mayoría de los autores en teología moral, hasta el presente, hayan sido sacerdotes o religiosos y, por tanto, celibatarios (150) manifestando un modo específico de vivir la sexualidad; la falta de mediaciones culturales al referirse al mundo de la sexualidad, entendiéndola como una realidad hecha y definitiva de una vez para siempre y no "traspasada" de condicionamientos sociales, psicológicos y, hasta, políticos. Es claro que ante esta obsesión se han producido reacciones (151). Sin embargo, como ocurre con frecuencia, dichas reacciones, en lo sustancial positivas, han dado origen a posiciones extremas donde se desconoce la validez de cualquier normatividad en la esfera sexual por considerarla frustrante o fuente de explotación o neurosis (152). Ciertamente que es sano terminar con la obsesión de lo sexual y que el sentimiento morboso de culpabilidad en esta materia hace daño a una moral auténtica y equilibrada. Sin embargo, la eliminación de toda consideración moral (153) torna frágil la conducta sexual dejándola expuesta a la

(148) Al iniciar la presentación del sexto mandamiento en su manual de teología moral para los futuros confesores, S. Alfonso dice lo siguiente: "A regañadientes comienzo el estudio de esta materia cuyo solo nombre mancha el espíritu del hombre. Perdóname, te lo ruego, casto lector, si ves aquí discutidas y explicadas numerosas cuestiones omitidas por el padre Busenbaum [otro moralista de la época]. Hubiera preferido expresarme de un modo más breve y más oscuro. Pero esta materia interviene frecuentemente y abundantemente en las confesiones. La mayoría de las almas van al infierno a causa de ella". Alfonso de Ligorio, Theología moralis, Roma, 1905, 1 I, lib III, tr.IV, cap.II, dub.I, n.413, 665-666.

(149) Hortelano, A., o.c. 536.

(150) "Y como la mayoría de los moralistas... son también célibes, se explica que, sin darnos cuenta, los célibes hayamos quizás proyectado en el mundo nuestro ideal virginal y también, a veces, nuestros complejos de represión y de angustia" Hortelano, A., o.c.537.

(151) Es el caso de Freud y el movimiento psicoanalista con su valoración de la 'libido'. En el campo católico es necesario mencionar a M. Oraison, sacerdote y psiquiatra, quien denunció con fuerza, a partir de su tesis doctoral (censurada por el Santo Oficio de la época), la obsesión sexual en el campo de la moral (Cf. Devant l'illusion et l'angoisse, París, 1962).

(152) Es la conocida tesis de W. Reich en su obra La irrupción de la moral sexual (1932) y también en La revolución sexual, obra esta que ha dado origen al movimiento del mismo nombre, con influencia hasta el presente. En "Mayo del 68" en Francia, uno de los "gurúes" de ese movimiento era Reich, junto a Marcuse y Sartre.

(153) Esta asepsia ética del mundo de lo sexual ha entrado profundamente en ambientes científicos y educativos. La tesis subyacente es la siguiente: la sexualidad humana no puede alienarse como tema moral, sino desplegarse con total libertad. Aquella no tiene nada que ver con las categorías de bien y mal. Esta tesis plantea su oposición frontal al pensamiento de la Iglesia que considera el acto sexual más allá del hecho biológico y lo vincula con valores de comunicación y encuentro, situándolo en la línea del 'misterio' y no solo del problema. El instinto sexual, según la posición que postula la prescindencia de la moral, es algo totalmente al margen de los valores, ni bueno ni malo, ni sucio ni limpio e introducir una consideración ética es contrario al tratamiento "científi- 
erosión del narcisismo y el egoísmo. Evitar la represión obsesiva sexual no quiere decir que no haya verdaderos pecados sexuales. Desconocer esto sería una verdadera anormalidad y una deformación en el juicio moral. El problema, como lo hemos reiterado, sin embargo, es aceptar su inexorable gravedad objetiva.

Una última consideración teológica puede aportar claridad a nuestra reflexión. Sin entrar en el complejo tema del pecado hoy, es posible distinguir, a la luz de la enseñanza evangélica, 'pecados de la carne' y 'pecados del espíritu', donde 'carne' y 'espíritu' tienen una significación específica. La primera, según la Escritura, mira al ser humano concreto con todas sus intrínsecas limitaciones y condicionamientos; el segundo se refiere a la persona abierta a Dios y apoyada en Él. Coherente con lo anterior, pecado de la carne implicaría un pecado de debilidad ("Velad y orad para que no caigáis en tentación. El espíritu está pronto, pero la carne es débil" Mt 26,41). Podría decirse, en categorías psicológicas, que el yo profundo no está totalmente comprometido en este tipo de pecado. Hay falta moral, de eso no cabe duda, pero afecta al yo superficial. Tal vez ahí esta la clave de comprensión de la actitud de Jesús ante la mujer adúltera: "No te condeno; vete y no peques más". El Señor no la condena, pero piensa que ha pecado y por ello la invita a cambiar de conducta. En cambio, el pecado contra el espíritu es un pecado que afecta al yo profundo. Compromete toda la existencia de la persona y consiste en cerrarse fría y sistemáticamente a Dios y a los hermanos. Como la persona se instala en esta actitud desde lo más profundo de su ser, este pecado no tiene perdón, es un "pecado contra el Espíritu" (Mt 12,31). Pareciera ser este el pecado que Jesús acusa a los fariseos al endurecer su corazón (Mc 12,38-39). Si Dios no perdona este tipo de pecado es porque el pecador permanece a ciencia y conciencia en una opción de rechazo al amor de Dios. Desde lo dicho se entiende mejor la tremenda afirmación de Jesús que, incluso hoy, puede llegar a escandalizar a más de alguno: "En verdad, en verdad os digo, que los ladrones y las prostitutas os precederán en el reino de los cielos". En conclusión, es probable que en materia sexual no siempre esté comprometido el yo profundo, lo que implicaría, de darse, en el campo de la moral, que se estaría optando radicalmente contra Dios. No se puede negar que ello ocurra desde el punto objetivo, pero no será lo frecuente (154).

co' del tema. La nueva moral -si puede hablarse así- debe reconocer el acto sexual y sus manifestaciones concomitantes como un valor en sí, como expresión de vitalidad, de una originalidad que refresca y libera. Enfoques de esta naturaleza están a la base de presentaciones de educación sexual: entregar solo información genital, teniendo verdaderos complejos para enunciar valores más allá de esa instrucción biológica. Es necesario señalar que esta asepsia valórica está internalizada en diversos ambientes docentes cuando se trata de educar para una sexualidad responsable e integral. Lo corroboran diversos programas de 'educación sexual' que circulan en medios, así llamados, 'científicos'.

(154) Hortelano introduce la categoría de "vértigo moral" para aplicarla a los pecados de índole sexual, a la luz de las actuales circunstancias ambientales: "El vértigo moral se parece al vértigo físico. Yo, por ejemplo, puedo muy bien caminar y hasta correr en tierra firme sobre una franja de veinte centímetros de ancho sin protección alguna y sin peligro de caerme. Pero en el alero de un tejado, a cien metros de altura y sin la protección de una barandilla, aunque tenga sesenta centímetros de ancho para correr, es casi seguro, si soy propenso al vértigo, que me caiga. Y me caigo sabiendo que me caigo y sin querer caerme. En lo moral puede ocurrir algo parecido. El hombre que está en estas circunstancias, que hemos descrito anteriormente, puede tener vértigo. Se da cuenta de que se cae, no quiere caerse y sin 
Vayamos concluyendo. Tenemos conciencia que no hemos presentado muchos otros desafíos. Aludimos, para dejar constancia que no es por olvido sino por no extender más la ponencia, algunos de ellos: la crisis de la socialización del amor en la cultura contemporánea: hay más "parejas" y menos matrimonios (155); la "normalidad" de las relaciones prematrimoniales que plantea un serio desafío pastoral para distinguir significados diferentes en ellas, habida cuenta de una moral desde la persona y no exclusivamente desde el objeto (156); el debate sobre el tema del "género" (157), el cual, al constituirse en una mediación cultural actual, debe ser asumido en la reflexión de la Iglesia sobre la sexualidad; la "denuncia" que hace algún intelectual contemporáneo acerca de la manipulación que -en ocasiones- se habría ejercido sobre las conciencias de las personas, especialmente en el confesionario, en materias de sexualidad, constituyéndose, ello, en un inadecuado ejercicio del poder (158), etc. Quisiéramos, con todo, solo mencionar un desafío más, sin explicarlo mayormente: llevar adelante trabajos interdisciplinarios para saber mucho más acerca de las actuales comprensiones que dan las ciencias médicas, psiquiátricas o psicológicas a específicos comportamientos sexuales. Es verdad que ellas son, en ocasiones, provisorias o propuestas como hipótesis de trabajo. Es el caso, para mencionar solo dos ejemplos, la comprensión de la conducta homosexual o la significación de la masturbación, de cara a los procesos de evolución psicosexual en un adolescente. Tenemos la impresión, no obstante, que la importancia que le ha otorgado la reflexión teológica a esas explicaciones es insuficiente o menor. Se ha escrito e investigado mucho en la materia y la teología debería interesarse más en los aportes que tengan mayor consistencia.

Llama la atención que el primer documento, después del Vaticano II, que se refiere "algo" a algunos de los temas mencionados es recién de 1974 (159), conociéndose, sin embargo, desde muchos años antes, por ejemplo, el pensamiento freudiano y estudios serios de sexología en la materia. La doctrina que se ofrecía, hasta ese momento, era la clásica, la cual venía prácticamente formulada desde Santo Tomás de Aquino y luego recogida y repetida en los manuales de moral a partir del Concilio de Trento. Hace falta mucha más investigación, realizada -en lo posiblepor moralistas "bilingües", es decir, expertos tanto en teología moral como serios

embargo se cae de hecho. Como decíamos, esto puede ocurrir fácilmente en el terreno de lo sexual a los hombres de nuestro tiempo". Hortelano, A., o.c. 541. Podrá decirse, como lo aconsejaba la moral tradicional, que la persona debiera apartarse de las ocasiones de pecado. El problema radica, sin embargo, que se vive inmerso en un ambiente fuertemente erotizado, donde se da una suerte de contaminación ambiental de la cual es difícil apartarse. Con todo, la moral clásica asimilará, probablemente, esta situación de vértigo moral a una circunstancia que hace disminuir en la persona su responsabilidad subjetiva, manteniendo, no obstante, la gravedad objetiva del comportamiento.

(155) Los datos del censo del año 2000 en Chile muestran un notorio descenso en los índices de nupcialidad. Sigue en ello la tendencia que se da en otros países.

(156) Cf. Romo, W., Las relaciones prematrimoniales, un desafío teológico-pastoral permanente y renovado, en Teología y Vida XXXI (1990) 279-308.

(157) Cf. Schickendantz, C., (Ed.) Mujeres, género y sexualidad. Una mirada interdisciplinar. Edit. Universidad Católica de Córdoba, Argentina, 2003.

(158) Cf. Foucault, M., Histoire de la sexualité 1: la volonté de savoir (especialmente cap. 3 Scientia Sexualis), París, 1976.

(159) Cf. Congregación para la Doctrina de la Fe, Declaración acerca de ciertas cuestiones de ética sexual, Ciudad del Vaticano, 1974. 
conocedores de las ciencias médicas o psicológicas o sexológicas. También es encomiable el esfuerzo por estudiar un mismo tema desde disciplinas diversas. Ya hay algunos estudios promisorios que van apareciendo (160) y que se unen a otros que asumen los nuevos paradigmas a partir de los cuales se está realizando en la actualidad la elaboración de la teología moral (161). El servicio que esta disciplina puede hacer al magisterio es urgente, necesario e imprescindible, aunque -en un primer momento- pudiera parecer conflictivo.

Este desafío de estudio e investigación nos ayudará a "decir" una mejor verdad acerca del hermoso don que Dios nos ha regalado al constituirnos en varón o en mujer. Y a partir de esa realidad sexuada llegar a ser, en el amor, "una sola persona" (basar), imagen humana de aquella otra Persona -el Espíritu Santo-, abrazo de amor eterno entre el Padre y el Hijo.

\section{RESUMEN}

El artículo presenta algunos de los desafíos contemporáneos a la credibilidad de la Iglesia sobre su enseñanza acerca de la sexualidad. Para iluminar estos desafíos los contextualiza al interior de una mirada histórica de cómo se ha desarrollado la enseñanza de la Iglesia desde sus orígenes hasta el Concilio Vaticano II. Enmarca, además, estos desafíos en una conceptualización integradora de la sexualidad humana, recurriendo para ello al aporte de diversas ciencias sociales. Reconociendo que los desafíos son muchos, privilegia algunos de ellos de cara a la cultura contemporánea: la necesidad de superar una visión maniquea pero también hedonista de la sexualidad, la valoración del placer sexual evitando hacerlo un absoluto, pero también sorteando una mirada negativa; aborda el problema del lenguaje como el Magisterio se ha referido a esta temática; se detiene en la significación de algunos comportamientos, especialmente en el mundo de la juventud, respecto a su comprensión de la sexualidad y la respuesta que recibe de la Iglesia en la materia.

\section{ABSTRACT}

The article presents some of the current challenges of the credibility of the church concerning its teachings on sexuality. The author sets them in a historical context which show how the teachings of the church developed from it origins to the Vatican Council II. These challenges are framed within an integrating conceptualisation of the human sexuality considering the contributions made by the various social sciences. The article acknowledges the presence of many challenges, but focuses on those most relevant in the contemporaneous culture: the need to overcome the maniquean view of sexuality, but also the hedonist one, the valorisation of the sexual pleasure without turning it into an absolute value, yet keeping from a negative view of it. It refers to the issue of the way the Magisterium has dealt with the language on this matter: taking notice of the significance of some conducts, especially among the youth, regarding their understanding of sexuality and the Church's response in this debate.

(160) Mencionamos, como un ejemplo, La homosexualidad, un debate abierto, Gafo, J., (Ed.), Bilbao, 1997, obra en la cual se presentan diversos artículos escritos por destacados especialistas en disciplinas afines que se refieren al mismo tema, desde sus respectivos enfoques.

(161) Cf. Gómez Mier, V., La refundación de la moral católica. El cambio de matriz disciplinar después del Concilio Vaticano II, Navarra, 1995. 